2016-07

\title{
Corporate debt maturity in the MENA region: Does institutional quality matter?
}

Awartani, B

http://hdl.handle.net/10026.1/5018

10.1016/j.irfa.2015.10.002

International Review of Financial Analysis

All content in PEARL is protected by copyright law. Author manuscripts are made available in accordance with publisher policies. Please cite only the published version using the details provided on the item record or document. In the absence of an open licence (e.g. Creative Commons), permissions for further reuse of content should be sought from the publisher or author. 


\title{
Corporate debt maturity in the MENA region: Does institutional quality matter?
}

\author{
Basel Awartani ${ }^{a}$, Mohamed Belkhir ${ }^{\mathrm{b}, *}$, Sabri Boubaker ${ }^{\mathrm{c}, \mathrm{d}}$, Aktham Maghyereh ${ }^{\mathrm{b}}$ \\ a Plymouth Graduate School of Management E Plymouth Business School, University of Plymouth, Plymouth, United Kingdom \\ b College of Business \& Economics, UAE University, Al Ain, United Arab Emirates \\ c Champagne School of Management, Troyes, France \\ d IRG, Université Paris Est, Créteil, France
}

\section{A R T I C L E I N F O}

Available online 23 October 2015

\section{JEL classification:}

G32

G33

G38

\section{Keywords:}

Debt maturity

Leverage

MENA

Institutions

Financial development

\begin{abstract}
A B S T R A C T
We investigate corporate debt maturity structure in the MENA region and its firm and institutional determinants using a sample of 444 listed firms over the 2003-2011 period, or 3717 firm-year observations. We find a very limited use of long-term debt by MENA firms; long-term debt represents only $3.41 \%$ of the typical MENA firm's total debt, which is much less than what is reported in prior literature on other parts of the world. Consistent with the predictions of debt maturity theories and prior empirical findings, we find that leverage, firm size, and asset tangibility are positively associated with the use of more long-term debt while firms facing a higher risk of default tend to use more short-term debt. In addition, we find that better quality institutions lead to the use of more long-term debt in MENA. Specifically, stronger rule of law, better regulatory effectiveness, better legal protection of creditors, and more developed financial intermediaries are associated with greater use of long-term borrowing by MENA firms. Our findings have important policy implications as they illuminate the path toward needed reforms that would enhance MENA firms' access to long-term debt, which may ultimately result in more private investment and jobs.
\end{abstract}

(c) 2015 Elsevier Inc. All rights reserved.

\section{Introduction and motivation}

Institutional theory suggests that institutions play an important role in a market economy to facilitate market interactions by lowering transaction and information costs (North, 1990). Institutional quality is particularly significant for companies operating in emerging markets. In many emerging markets, institutions, which in North's (1990) words, provide the formal and informal rules of the game in a market economy, are malfunctioning or not even in place. Such absence of well-functioning institutions can amplify information asymmetry and magnify transaction costs (Meyer, 2001). Improvements in the institutional framework are known to lower the costs of doing business (e.g., Bevan, Estrin, \& Meyer, 2004). The insights of institutional theory were used to examine corporate financing choices across both developed and emerging countries. The findings suggest that institutional quality plays a pivotal role in explaining cross-country differences in corporate financing choices and that enhancing the institutional framework would benefit access to finance in emerging markets.

Focusing on debt maturity, Demirgüç-Kunt and Maksimovic (1999), Giannetti (2003), Qian and Strahan (2007), Bae and Goyal (2009), and Fan, Titman, and Twite (2012) provide empirical evidence that a country's level of investor protection and the quality of its law enforcement influence firm debt maturity. Specifically, these studies find that creditors

\footnotetext{
* Corresponding author.

E-mail address: m.belkhir@uaeu.ac.ae (M. Belkhir).
}

respond to poor protection and weak law enforcement by shortening loan maturities. This evidence is consistent with Diamond's (2004; p. 1464) theoretical argument that "if enforcement costs are large and creditor protection is weak, then borrowers rely more heavily on shortterm debt." Other studies emphasize the role of other institutional dimensions in corporate debt maturity structure. Consistent with the view that national culture helps explain cross-country variations in the maturity of structure of corporate debt, Zheng, El Ghoul, Guedhami, and Kwok (2012) report evidence that firms located in countries with high uncertainty avoidance, high collectivism, high power distance, and high masculinity tend to use more short-term debt. Using a cross-country analysis, El Ghoul, Guedhami, Pittman, and Rizeanu (2014) argue and find evidence that better auditor quality increases the use of long-term debt by firms. Belkhir, Ben-Nasr, and Boubaker (2014) further find that corporate debt maturity is influenced by the extent to which a country's laws and regulations provide protection to the labor force; more labor protection leads to shorter maturity of corporate borrowings.

Motivated by this growing body of literature pointing to the importance of a country's institutions to firm-level debt maturity choices, we examine the role of institutional quality in determining corporate debt maturity in the Middle East and North Africa region (MENA hereafter). We attempt to answer three questions: (1) what is the state of firm debt maturity in the MENA region? (2) Is debt maturity in MENA countries determined by the same firm-level factors as those identified in other parts of the world, especially emerging countries? (3) Do 
institutional factors explain differences in firm debt maturity across the region's countries? To answer these questions, we use a sample of firms from ten MENA countries, which are Bahrain, Egypt, Jordan, Kuwait, Morocco, Oman, Qatar, Saudi Arabia, Tunisia, and the United Arab Emirates (UAE). To the best of our knowledge, this is the first comprehensive study of corporate debt maturity in the MENA region. As much as is known, there is no prior research dedicated to the issue of firm debt maturity in this specific region. Further, cross-country studies on debt maturity tend to exclude MENA countries from their coverage. For instance, to examine the determinants of corporate debt maturity, Zheng et al. (2012) and Fan et al. (2012) use samples of 40 and 39 countries, respectively, but none of them is from the MENA region. El Ghoul et al. (2014) use a sample of 42 countries, of which only Egypt is from the MENA region. We fill this gap in the literature and illuminate an important dimension of firm financial structure - debt maturity - in a region where institutional quality represents a major challenge to firms.

There are several reasons that make the study of corporate debt maturity in the MENA region an important one. First, as most MENA countries suffer from high unemployment rates and low private investment rates, access to financing, especially long-term debt, becomes critical to any attempt to reverse such situation. ${ }^{1}$ In particular, private long-term investments that create jobs require access to long-term debt. Examining firms' access to long-term borrowing and its determinants can shed light on potential remedies to alleviate the region's thorny problem of low investment rates and high unemployment. Second, while facing a challenging geopolitical environment, most MENA countries have been striving to modernize their economies and to integrate their capital markets in world markets. Signs of such endeavors include the recent upgrading of UAE and Qatar's equity markets from frontier to emerging by index compiler MSCI and the 2014 decision of Saudi Arabia to open its $\$ 550$ billion stock market to direct investment by foreign institutions. Such moves are expected to increase foreign investors' interest in the region's companies whose financing and investment decisions ought to converge toward those of firms located in more developed markets. Investigating debt maturity structure of the region's firms thus informs on whether their financing practices are in step with those observed in advanced economies. Third, 40.2\% of MENA firms identify access to external finance as a major challenge to doing business. ${ }^{2}$ At the same time, it is well known that MENA countries are characterized by weak institutional environments; financial systems are still lagging behind in terms of size and efficiency and public governance and investor protection are often deficient. An empirical assessment of the actual influence of the institutional environment on debt maturity is of utmost importance as it adds to our understanding of the needed reforms that might improve firms' financing opportunities and therefore investment and job creation.

We examine corporate debt maturity and its firm and institutional determinants in MENA in a sample of 444 listed firms over the 20032011 period, or 3717 firm-year observations. Our most striking finding is that firms' use of long-term debt, measured as debt maturing in more than 1 year, is very scarce across the MENA region. The typical firm in MENA, if taken as a whole, has only $3.41 \%$ of its total debt as long-term debt. The use of long-term debt varies from one country to another. The weakest use of long-term debt is observed in Egypt where long-term debt of the typical firm represents only $2.45 \%$ of total debt. Oman is the country where the use of long-term debt is the most prevalent among all our sample countries; long-term debt of the typical firm represents $8.10 \%$ of total debt. By way of comparison, the use of long-term debt in any MENA country is lower than in any of the countries reported in prior studies on debt maturity (e.g., El Ghoul

\footnotetext{
1 According to recent IMF and World Bank statistics, unemployment in the MENA region is the highest in the world - a rate close to $20 \%$, with youth unemployment rate reaching up to $25 \%$; this rate reaches up to about $30 \%$ in Tunisia. The average MENA private investment rate is about 15\% of GDP (IMF 2013 statistics).

2 Data available on www.enterprisesurveys.com, accessed on February 09, 2015.
}

et al., 2014; Fan et al., 2012; Kirch \& Terra, 2012; Demirgüç-Kunt \& Maksimovic, 1999). In sum, MENA firms rely much less on long-term debt compared not only to firms located in developed countries but also to those located in developing countries reported in prior studies.

Examining firm-level determinants of debt maturity in MENA, we find that, consistent with prior studies, leverage, firm size, asset tangibility, and risk of default are consistently related to the use of long-term debt. Specifically, larger firms, firms with a greater capacity to borrow - with more leverage - firms holding more tangible assets, and firms facing a lower risk of default tend to raise more long-term debt. These findings hold in a country-by-country analysis as well as in a cross-country setting where we pool all firm-year observations together. They imply that the use of long-term debt in MENA countries responds to the same firmlevel factors identified by prior theoretical and empirical debt maturity literature (e.g., Myers, 1977; Barnea, Haugen, \& Senbet, 1980; Flannery, 1986; Diamond, 1991; Barclay \& Smith, 1995; Stohs \& Mauer, 1996; Johnson, 2003; Custódio, Ferreira, \& Laureano, 2013, etc).

Besides firm-level factors, we examine whether the quality of institutions with direct relevance to firm financing has an influence on the extent to which firms in MENA countries use long-term debt. Specifically, we examine whether the quality of public governance, financial development, and creditor rights impact the use of long-term debt. To capture the quality of public governance, we rely on three different indicators that measure the rule of law (RL), regulatory effectiveness (RE), and corruption (CORR). We find robust evidence that stronger rule of law and better regulatory effectiveness are conducive to greater reliance on long-term debt by MENA firms. Firms operating in MENA countries with a relatively stronger rule of law and a greater regulatory effectiveness are seemingly more able to raise more long-term debt. We also find that more corruption leads to the use of longer-term debt maturity structures. Corruption seems to ease firms' access to long-term debt by helping firm managers in overcoming stringent bank policies related to long-term lending. As regards financial development, we find that firms operating in the presence of more developed financial intermediaries use more long-term debt. Stock market development has, however, no impact on the use of long-term debt. Finally, using Djankov, McLiesh, and Shleifer's (2007) creditor rights' index, we report evidence that better legal protection of creditors leads to more longterm in MENA firms' balance sheets. The results obtained using the random effects model are robust to the use of alternative specifications, such as the simple regression model, firm fixed effects panel model, 2SLS, Tobit estimation, and the IV-GMM method. Similarly, an alternative measure of debt maturity such as the ratio of long-term liabilities to total liabilities yields qualitatively similar results.

Our study of corporate debt maturity and its determinants in MENA contributes to a growing body of literature highlighting the importance of institutional quality to firms' access to long-term debt. DemirgüçKunt and Maksimovic (1999); Giannetti (2003); Antoniou, Guney, and Paudyal (2008); Bae and Goyal (2009); Fan et al. (2012), and Zheng et al. (2012) show that firms operating in better quality institutional environments tend to use more long-term debt. We add to their findings by providing evidence, from a region that has not been covered by prior literature, that in very weak institutional environments, firms' use of long-term debt can be extremely low. Our study also adds to a strand of literature that focuses on corporate debt maturity structure in developing countries. While quite scarce, this literature provides important insights on the constraints faced by firms from developing countries in raising external finance. In this regard, our study intersects with Kirch and Terra's (2012) and Cai, Fairchild, and Guney's (2008) works on corporate debt maturity structures in South American countries and in China, respectively. We augment their findings with evidence, from the MENA region, suggesting that strengthening the rule of law, providing better legal protection to creditors, and developing the financial system should ease firms' constraints to access long-term debt and ultimately enhance investment and job creation. 
The rest of the paper is organized as follows. Section 2 reviews the theories of the determinants of the firm's debt maturity. The section also discusses the role of institutional factors. In section 3 , we describe our sample and we provide summary statistics on average debt maturity of firms across MENA countries. The models used and the analysis of the influence of institutional variables as well as other variables on debt maturity are included in section 4 . Finally in section 5 , we provide some concluding remarks.

\section{Institutions and debt maturity in MENA}

\subsection{Debt maturity: Prior literature}

Since Stiglitz's (1974) proposition on the irrelevance of the choice of debt maturity structure, much research effort has been directed to better understand the determinants of debt maturity. The works of Myers (1977), Barnea et al. (1980), Brick and Ravid (1985), Flannery (1986), and Diamond (1991), among others, have provided a solid starting point for this literature by proposing a number of theories to explain the firm's debt maturity structure. For instance, Myers (1977) and Barnea et al. (1980) argue that firms can mitigate the agency conflicts between shareholders and debtholders by shortening the maturity of their debt since long-term debt is less effective than short-term debt in reducing agency costs. Moreover, Myers (1977) and Chang (1989) point out that firms can alleviate these agency conflicts by matching the maturity of their liabilities to the expected life of their assets. Flannery (1986) and Kale and Noe (1990) argue that in the presence of information asymmetry between firm insiders and outsiders, debt maturity can be used as a signal of the quality of the firm's investments; high-quality firms prefer to issue short-term debt whereas low-quality ones prefer to issue long-term debt. Firm's liquidity risk has also been shown to be a potential driver of the choice of debt maturity structure (Diamond, 1991). Furthermore, other studies offer a tax-based rationale for debt maturity. In this vein, Kane, Marcus, and MacDonald (1985) and Brick and Ravid (1985), for instance, demonstrate that the optimal debt maturity structure depends on the tax benefits of debt financing.

The empirical work that examines the determinants of debt maturity falls into two main strands. The first strand analyzes the impact of firm characteristics on debt maturity within individual countries. Most of the empirical studies on this issue focus on the U.S. market. Barclay and Smith (1995) find that firms with more growth options use less long-term debt in their capital structure. This finding is consistent with Myers's (1977) prediction that firms with higher growth opportunities tend to shorten the maturity of their debt as a way of mitigating the agency conflicts between debtholders and shareholders. Stohs and Mauer (1996) find evidence suggesting that debt maturity can signal information about firm quality, consistent with Flannery (1986). Moreover, their results corroborate the theoretical predictions linking debt maturity to taxes, liquidity risk, and asset maturity. More recently, empirical studies emphasize the role of corporate governance in the choice of debt maturity. Datta, Iskandar-Datta, and Raman (2005); Jiraporn and Kitsabunnarat (2007); Harford, Li, and Zhao (2008); and Brockman, Martin, and Unlu (2010) show that managerial ownership, the strength of shareholder rights, the strength of the board of directors, and CEO compensation incentives affect debt maturity choice, respectively. Research on non-US firms remains, however, scarce. For instance, Ozkan (2000), Shyu and Lee (2009), and García-Teruel and Martínez-Solano (2010) investigate maturity structure of corporate debt in the UK, Taiwan, and Spain, respectively.

The second strand of empirical literature focuses on the countryspecific determinants of corporate debt maturity. Demirgüç-Kunt and Maksimovic (1999) provide evidence that differences in financial and legal institutions and macroeconomic factors affect the choice of debt maturity. Using data on unlisted companies from several European countries, Giannetti (2003) finds important differences across countries in how debt maturity is determined. Antoniou, Guney, and Paudyal
(2006) examine the determinants of debt maturity structure using samples of French, German, and British firms. They find that the financial systems and institutional traditions of these countries are important determinants of debt maturity. Studying South American countries, Kirch and Terra (2012) show that a country's level of institutional quality has a first-order effect on the maturity structure of corporate debt. Zheng et al. (2012) investigate the influence of national culture on the choice of debt maturity. Their findings corroborate the view that national culture is an important determinant of the cross-country variations in corporate debt maturity. Fan et al. (2012) provide evidence that firms from countries with weak laws and government corruption have shorter debt maturities, and those from countries with deposit insurance or explicit bankruptcy codes tend to have longer debt maturities. These findings imply that the institutional environment importantly affects the maturity structure of corporate debt.

\subsection{MENA region's institutional framework}

Prior literature summarized in the previous section documents evidence of the relevance of countries' institutions to firms' debt maturity structures. In this section, we provide a description of the quality of the institutional environment in MENA countries, which may help in predicting and understanding the debt maturity structure of firms operating in this region. In this discussion, we approach the region as a whole and emphasize institutions with implications to firms' access to long-term debt. We particularly focus on the quality of public governance, the financial sector, and the state of creditor rights and insolvency regimes.

\subsubsection{Public governance}

Good public governance fosters investors' confidence that their claims and property rights are well protected against expropriation by both the government and private agents. It thereby enhances their investment incentives. MENA region's business climate has been plagued by deficient public institutions that failed to act efficiently and in accordance with the rule of law. Recent reports by international organizations, such as the World Bank and Transparency International, show that most MENA countries are lagging behind in international rankings that classify countries according to various dimensions of public governance, suggesting a great need for substantial actions to boost public governance in the region. For instance, based on its Corruption Perceptions Index, Transparency International consistently ranks MENA countries below the world median, indicating widespread corruption across the region and a failure over the years to combat this prevalent problem. ${ }^{3}$ Likewise, the World Bank's 2013 Governance Indicators show evidence of weak rule of law, widespread corruption, and regulatory ineffectiveness across the region. The region is characterized by relatively weak formal systems of checks and balances... There is a relative lack of accountability institutions that are truly independent, such as supreme audit agencies, the cours des comptes, ombudsmen or anticorruption agencies." ${ }^{4}$ Weak public governance is likely to have a severe negative impact on a country's business climate. It, especially, can hinder firms' access to credit at favorable conditions.

\subsubsection{Financial systems}

Despite their praise of efforts made by MENA countries to develop their financial sectors, reports issued by most international organizations - IMF, World Bank, OECD, etc. - tend to agree that, on average,

\footnotetext{
${ }^{3}$ See, for instance, Transparency International (2013) report available on http://www. transparency.org/cpi2013. However, it is worth noticing that some countries are performing better than others when it comes to corruption control, as in 2013, the UAE and Qatar scored above the median line of the Corruption Perceptions Index.

${ }^{4}$ Robert Beschel (2014). "Corruption in MENA: Declining Trend or More of the Same?", available on: http://web.worldbank.org/WBSITE/EXTERNAL/COUNTRIES/MENAEXT/ EXTMNAREGTOPPOVRED/0,,contentMDK:22475226 pagePK:34004173 piPK:34003707 theSitePK:497110,00.html.
} 
this region's financial systems remain among the least developed in the world. One of the indicators of this underdevelopment of the financial system is the tendency of MENA countries, especially oil-exporting countries, to invest their savings through financial sectors based in foreign countries - both advanced and emerging ones. In the 2012 Financial Development Report issued by the World Economic Forum, the MENA country with the most developed financial system, Kuwait, is ranked 21st among sixty-two countries classified according to a financial development index. While such rank can be considered as decent, it however hides several deficiencies that prevent the existence of a well-functioning financial system. Such deficiencies are common across the MENA countries. One of these deficiencies is the quasi-exclusive reliance on bank intermediation as a channel of savings to productive sectors; MENA financial systems are heavily bank-based with a minor role played by equity markets and a quasi-absence of debt capital markets.

For instance, bond issuances totaled only USD83.9 billion in 2012. Of these issuances, only USD37 billion (44\%) were corporate issues while the rest were sovereign issues. This is trivial compared to other parts of the world, as in the same year, the worldwide volume of corporate bond issues amounted to USD3.1 trillion of which USD1 trillion were issued in emerging markets. The Global Financial Stability Report issued by the IMF in 2004 reveals that bank assets accounted for $85 \%$ of financial assets in the MENA region, which is much higher than in emerging Asian countries (48\%), in emerging Europe (41\%), and in Latin America (35\%). A recent report by the World Bank (2009) confirms this tendency; equity market capitalization of non-financial corporations represents only $12 \%$ of GDP whereas the stock of private fixed income instruments is negligible. ${ }^{5}$

The banking sector which is the most important source of external capital for private businesses is, in most countries, plagued by high levels of government ownership and lack of competition. For instance, government ownership of the banking sector amounts to 21\% in Saudi Arabia, 34\% in Kuwait, 60\% in Egypt, and 70\% in the UAE. ${ }^{6}$ Likewise, in most of these countries, the banking sector is highly concentrated and barriers to entry of new banks are typically high (Turk-Ariss, 2009; Anzoategui, Martinez Peria, \& Rocha, 2010). High government ownership and concentration are likely to cause inefficiency in credit allocation and deficient risk management systems.

\subsubsection{Creditor rights and insolvency regimes}

A country's creditor rights and insolvency regime is an important institutional framework that determines firms' access to credit. This framework encompasses the extent to which creditors can repossess collateral, reorganize the defaulting borrower, and recover the loaned capital upon default. Theoretical research (e.g., Diamond, 2004) and empirical evidence (e.g., Bae \& Goyal, 2009; Qian \& Strahan, 2007) suggest that firms located in countries with stronger creditor rights and contract enforcement tend to raise more debt capital at better terms. Djankov et al. (2007) report that creditor rights vary extensively from one country to another, with consequences for access to credit by private companies; a country's ratio of private sector credit to GDP increases with the strength of creditor rights. Araujo, Ferreira, and Funchal (2012) find that reforming bankruptcy law in Brazil, in a way that strengthened creditors' rights, resulted in increases of $10 \%$ and $23 \%$ in the amount of firm total debt and long-term debt, respectively. In sum, better protection of creditors through a sound insolvency regime enhances their [creditors] incentives' to lend at favorable terms.

In MENA countries, regulations and institutions remain weak and inefficient in protecting creditor rights. For instance, insolvency systems are generally inefficient in settling firm insolvency through reorganization or liquidation. According to the Doing Business Report of the World Bank (2014), creditors in MENA countries can expect to recover, on

\footnotetext{
${ }^{5}$ World Bank (2009). "Financial Access and Stability: A Road Map for the Middle East and North Africa."

${ }^{6}$ Financial Development Report (2012) issued by the World Economic Forum
}

average, only 26.6 cents on a dollar from insolvent firms; a recovery rate which is lower than in any other region, except Sub-Saharan Africa. ${ }^{7}$ Likewise, insolvency resolution is highly costly in MENA countries as it amounts to $14 \%$ of the value of the debtor's estate, compared with $9 \%$ in OECD high-income countries. Moreover, the MENA region average time to resolve insolvency is the longest compared to all other regions -3.1 years. While these indicators vary extensively across MENA countries, they suggest that, overall, firms and creditors in the region face inefficient insolvency processes that make the recovery of credit costly and slow.

Collateral is an important trigger for banks' decisions to extent extend credit in the MENA region; the most recent data of the Enterprise Survey of the World Bank show that $77.3 \%$ of loans require collateral and that the value of collateral needed for a loan represents $193.4 \%$ of the amount of the loan. ${ }^{8}$ In spite of the importance of collateral for access to credit, most MENA countries suffer from the lack of strong collateral legal regimes. This may be an additional hurdle to MENA firms' access to credit at favorable terms, as Haselmann and Wachtel's (2010)findings suggest that well-functioning collateral regimes increase bankers' incentives to lend. In most MENA countries, nonpossessory interests in movable collateral are not recognized by the law and priority rules between secured creditors in case of borrower default are not well established. Registration, enforcement, and liquidation of collateral, especially movable collateral, is a major concern for lenders and borrowers alike, which, according to Alvarez de la Campa (2011), reduces the amount of loans secured with movable collateral.

\subsection{Predictions}

Throughout this study, our main measure of firm debt maturity is the ratio of long-term debt (maturing in more than 1 year) to the sum of long-term debt and debt in current liabilities. This measure which we label DMAT has been widely used in the debt maturity literature (e.g., Demirgüç-Kunt \& Maksimovic, 1999; Antoniou et al., 2006; Fan et al., 2012; El Ghoul et al., 2014; Belkhir et al., 2014). In further analyses, we check the robustness of our analyses to the use of alternative measures of debt maturity.

To examine debt maturity structure in the MENA region, we use two sets of determinants: (1) firm-level factors and (2) country-level factors. In what follows, we first identify a set of common firm-level factors reported in most debt maturity studies as having a significant impact on corporate debt maturity. We discuss their potential influence on debt maturity based on theories of debt maturity, including signaling and liquidity risk, asymmetric information, agency costs, and taxation and report the findings of prior studies. We, then, introduce and discuss country-level factors that may potentially impact firm debt maturity in the MENA region.

\subsubsection{Firm-level factors and debt maturity}

2.3.1.1. Leverage. More levered firms face a greater liquidity risk and are hence expected to borrow with longer terms to maturity to mitigate such risk (Stohs \& Mauer, 1996; Johnson, 2003; Custódio et al., 2013). Moreover, since more levered firms are more exposed to default risk, they may prefer to use more long-term debt to reduce such exposure (Morris, 1992). Examining optimal capital structure in the presence of taxes and agency and bankruptcy costs, Leland and Toft (1996) show that the two dimensions of capital structure - amount and maturity are the result of a tradeoff between tax advantages, bankruptcy costs, and agency costs and that firms using more short-term debt also have a lower optimal leverage. We measure leverage (LEV) by the ratio of

\footnotetext{
7 The recovery rate is $70.6 \%$ in OECD high-income countries.

8 Based on datasets available on www.enterprisesurveys.org, accessed on January 05 , 2015.
} 
total debt to total assets and expect it to have a positive association with debt maturity.

\subsubsection{Firm size. Debt maturity may be affected by firm size for several} reasons, such as financial condition and information asymmetry. Larger firms are expected to face less information asymmetry and may therefore be able to use more long-term debt (Custódio et al., 2013). In the same vein, Titman and Wessels (1988) suggest that the use of shortterm debt is more prevalent in small firms compared to large ones due to the high transaction costs that small firms may face when issuing long-term debt. Larger firms may also have easier access to long-term debt due to a better financial condition (e.g., Johnson, 2003). Overall, empirical studies tend to report a positive association between firm size and debt maturity (e.g., Barclay \& Smith, 1995; Stohs \& Mauer, 1996; Guedes \& Oplar, 1996; El Ghoul et al., 2014). We measure firm size (SIZE) by the natural logarithm of total assets and expect it to be positively associated with debt maturity in the MENA region.

\subsubsection{Growth opportunities. In Myers' s (1977) model, firms with} growth opportunities can mitigate the underinvestment problem due to the conflict of interest between stockholders and debt holders through the use of short-term debt. Consistent with this idea, Barclay and Smith (1995); Guedes and Oplar (1996); Barclay, Marx, and Smith (2003); and Johnson (2003), among others, find that debt maturity is negatively associated with growth opportunities. In a sample of U.S initial public debt offerings, Datta, Iskandar-Datta, and Patel (2000) report an inverse relation between future growth opportunities and corporate bond term-to-maturity. We measure growth opportunities (GROWTH) as the ratio of the market value of equity plus the book value of debt to book value of assets. We expect GROWTH to be negatively associated with debt maturity.

2.3.1.4. Asset tangibility. Hart and Moore (1994) argue that when assets retain value, the investor retains the ability to extract repayment and can lend longer-term. Analyzing the optimal structure of debt, Berglöf and Von Thadden (1994) conclude that firms with tangible assets should be financed with long-term debt. In their paradox of liquidity theory, Myers and Rajan (1998) argue that asset illiquidity (tangibility) increases the likelihood that the assets will "be there," and gives creditors more time to assess their values and risks, which allows firms with more tangible assets to raise more long-term debt. Kirch and Terra (2012) and Custódio et al. (2013) report a positive relation between asset tangibility and the use of long-term debt. We use the ratio of property, plant, and equipment to total assets (PPE) as a proxy for asset tangibility and expect it to be positively associated with debt maturity.

2.3.1.5. Asset maturity. According to Myers (1977), the underinvestment problem can be mitigated by scheduling debt repayments to correspond to the decline in future values of the firm's assets in place: matching the maturity of the firm's debt to the maturity of its assets. Hart and Moore (1994) argue that the optimal repayment path of debt is affected both by the maturity structure of the firm's projects' return streams and by the durability of the projects' assets. Assets with longer maturity should thereby lead to the use of more long-term debt and vice versa. The empirical literature finds that asset maturity tends to have a positive influence on debt maturity (e.g., Stohs \& Mauer, 1996; Guedes \& Oplar, 1996; Barclay et al., 2003; Antoniou et al., 2006; Cai et al., 2008; Custódio et al., 2013). We measure asset maturity (AMAT) as the weighted average of the maturities of long-term and current assets and expect that firms with longer asset maturities use more long-term debt.

2.3.1.6. Default risk. Custódio et al. (2013) argue that firms with a higher probability of default might be excluded from the long-term debt market. In their model of optimal debt policy, Kane et al. (1985) suggest that firms with less volatile asset returns - less default risk - have a longer optimal debt maturity. Sarkar (1999) models the debt maturity decision in the presence of default risk and predicts that bond maturity decreases with the issuer's risk of default. Empirical studies generally report a negative relation between default risk and the term-to-maturity of corporate debt (e.g., Guedes \& Oplar, 1996; Custódio et al., 2013). We use Altman's Zscore as modified by MacKie-Mason (1990) as a measure of default risk (Z-SCORE). Higher values of Z-SCORE indicate a lower probability of default. Z-SCORE is expected to be positively associated with debt maturity since firms with a lower likelihood of default might have better access to the market for long-term debt.

2.3.1.7. Firm quality. In the presence of asymmetric information, debt maturity can be used as a signal of the quality of a firm's investments. Specifically, Flannery (1986) and Kale and Noe (1990) argue that because of the greater sensitivity of long-term debt to firm value, longterm debt can be subject to more mispricing than short-term debt. Firms with better quality investments are more likely to use more of the less undervalued short-term debt whereas firms with lower quality investments are more likely to use more of the overvalued long-term debt. We use the return on assets (ROA) as a proxy for the quality of a firm's investment projects and expect it to be negatively associated with the maturity of debt.

2.3.1.8. Taxation. A firm's debt maturity may also be affected by its effective tax rate. For instance, using an option valuation model that accounts for the presence of bankruptcy costs, flotation costs, and tax advantages to debt, Kane et al. (1985) show that a firm's optimal debt maturity increases with the fall in the tax advantage of debt; at a lower tax advantage, a longer maturity is required to amortize the flotation costs of issuing debt. Empirical findings regarding the relation between effective corporate tax rates and debt maturity vary, however, from one study to another. For instance, Guedes and Oplar (1996) find that debt maturity is negatively related to corporate tax rates whereas Antoniou et al. (2006) and Zheng et al. (2012) find no significant relation between the two variables. To account for the potential impact of effective tax rates on debt maturity, we include the effective tax rate (ETR) in our debt maturity models. ETR is calculated as the ratio of income taxes to pre-tax income.

\subsubsection{MENA institutions and debt maturity}

To capture the role of institutional quality in determining corporate debt maturity structure across the MENA region, we rely on several indicators that capture the quality of public governance, financial development, and creditor rights. As regards public governance, we use three indicators which capture three critical different dimensions of the quality of public governance: rule of law, regulatory effectiveness, and corruption. We use two indicators of financial development to investigate the impact of the financial system on corporate debt maturity. Finally, we use an indicator of the strength of creditor rights to estimate the impact of creditors' protection on debt maturity.

2.3.2.1. Rule of law. The rule of law refers to the legal principle that the behavior of government institutions and officials as well of private entities is subject to the supremacy of law. To examine whether abidance by the rule of law affects firm debt maturity in MENA countries, we use the rule of law index developed by the World Bank (RL). This index reflects economic agents' perceptions of the quality of contract enforcement, property rights, the police, as well as justice. RL ranges from -2.5 to 2.5 , with greater values indicating a stronger rule of law. In countries with weak rule of law, expropriation of investors by managers and firms is easier. As argued by Diamond (1991, 2004) and Rajan (1992), this is likely to increase the use of short-term debt as the latter makes expropriation of creditors by borrowers more difficult. With short maturities, borrowers are subject to more frequent monitoring by creditors 
and expropriation risk is limited. We, thus, expect that firms located in countries with relatively stronger rule of law issue more long-term debt.

2.3.2.2. Regulatory effectiveness. Regulatory effectiveness encompasses a government's ability to legislate and implement policies and regulations aimed at improving the business environment and fostering entrepreneurship and investment. To assess the potential impact of regulatory effectiveness on corporate debt maturity in the MENA region, we use the World Bank's regulatory quality index, which varies from -2.5 to 2.5 , with greater values indicating a greater effectiveness in enacting and implementing legislations that enhance firms' and individuals' capabilities of doing business. We label this measure RE and expect it to have a positive impact on firm debt maturity.

2.3.2.3. Corruption. When it comes to raising external finance, widespread corruption may increase the cost of long-term loans due to the costly bribes that firms may need to disburse to bankers and/or government officials to access such (risky) loans. In such a case, the more corruption a country has, the lower the long-term debt that firms can raise. Yet, one can also argue that corruption may help firms in overcoming stringent bank policies related to long-term lending and therefore ease firms' access to long-term debt. If this is the case, more corruption should lead to the use of more long-term debt, all else being equal. We use the World Bank index of corruption as a proxy for a country's control of corruption (CORR). The index reflects perceptions of the extent to which public power is exercised for private gain, including both petty and grand forms of corruption, as well as "capture" of the state by elites and private interests. The index ranges from -2.5 to 2.5 , with greater values indicating a stronger control of corruption. Whether higher levels of corruption lead to the use of more or less long-term debt by firms is an empirical question.

2.3.2.4. Financial development. According to Demirguc-Kunt and Maksimovic (1998, p. 2108), "the existence of developed and active financial markets and a large intermediary sector should make it easier for firms to raise long-term capital." Well-developed financial systems may enhance firms' access to long-term debt especially through increasing the availability of information on borrowers. For instance, Grossman (1976); Llorente, Michaely, Saar, and Wang (2002); and Albuquerque, Bauer, and Schneider (2009)suggest that share trade in equity markets conveys substantial information on firms' prospects. This available information reduces the risk of lending to listed firms. Thus, the existence of well-developed equity markets should foster firms' long-term borrowing capabilities. Further, financial intermediaries can achieve scale economies in collecting information (e.g., Diamond, 1984) and curtail moral hazard through effective monitoring, lowering thereby the cost of long-term debt. Hence, the presence of an active financial intermediation sector would increase firms' reliance on long-term debt. To account for the potential impact of financial development on firm debt maturity structure, our debt maturity model includes a measure of financial intermediation development (FIND) and a measure of stock market development (SMD). FIND is calculated as the ratio of domestic credit provided by the financial sector to GDP and captures the extent to which the banking sector and other finance companies are willing to extend credit to enterprises. As in Giannetti (2003), we use the ratio of stock market capitalization to GDP as a proxy for stock market development (SMD); this ratio captures the size of a country's stock market. ${ }^{9}$

\footnotetext{
${ }^{9}$ It is worth noticing that financial development can be measured in several ways and that the literature provides no clear-cut guidance as to which measures are best. In further analyses, we use alternative measures of stock market development and financial intermediary development. We discuss results based on these alternative measures in the Empirical Evidence section.
}

2.3.2.5. Creditor rights. The extent to which creditors are protected against borrower expropriation, especially in the event of default, is considered to be of paramount importance for firms' use of long-term debt. However, there are two conflicting views on the way creditor legal protection affects the maturity of corporate borrowings. The first view holds that stronger creditor protection would induce firms to issue more long-term debt. With better legal protection, creditors face less risk of expropriation and are thus more willing to extend credit at favorable terms, including long-term credit. This, in turn, leads firms to use more long-term debt. Empirical findings consistent with this view are reported in Giannetti (2003), Qian and Strahan (2007), Antoniou et al. (2008), and Fan et al. (2012). The alternative view hypothesizes that stronger creditor protection would reduce firms' reliance on debt, particularly long-term debt. In strong creditor protection jurisdictions, creditors are generally placed at an advantage over managers and shareholders; upon default, creditors can seize the firm's assets, remove managers, and force liquidation and repayment. Aware of such threat, self-interested managers can reduce the risk of losing control by avoiding to raise risky capital such as long-term debt. Empirical evidence in this direction can be found in Vig (2013) and Cho, El Ghoul, Guedhami, and Suh (2014). We account for the potential influence of creditor protection on debt maturity in the MENA region by including the creditors' rights index of Djankov et al. (2007) in our regression equations. The creditors' rights index which we label CR ranges from 0 (poor creditor rights) to 4 (strong creditor rights). Whether there is a positive or negative association between CR and debt maturity is, however, an empirical issue.

Consistent with prior literature on corporate debt maturity (e.g., Demirgüç-Kunt \& Maksimovic, 1999; Fan et al., 2012; Cho et al., 2014), we also control, in our multivariate analysis, for two macroeconomic factors: GDP growth rate (GDPG) and the inflation rate (INF). Besides the firm and country-level controls, we also include year and industry fixed effects to reduce the potential effect of omitted variables.

\section{Data, descriptive statistics, and empirical methods}

\subsection{Data}

The firm-level data used in this study are obtained from the FitchIBCA Worldscope database. Macroeconomic data - GDP growth and inflation rates - are collected from the IMF's International Financial Statistics, whereas country-level institutional variables are obtained from various sources, such as the Financial Structure Database and the Governance Indicators Database of the World Bank, and the Heritage Foundation. We report detailed descriptions and sources of all variables used in the analysis in Table 1.

Our sample includes listed firms from 10 MENA countries. The countries are Bahrain, Egypt, Jordan, Kuwait, Morocco, Oman, Qatar, Saudi Arabia, Tunisia, and the UAE. ${ }^{10}$ We use annual data over the period 2003-2011. In line with prior research, we exclude all financial firms whose leverage decisions are determined by different factors. We require that firms have at least three consecutive years of available data over the sample period to be included in the sample. Moreover, we exclude firms with negative book equity. We end up with a final sample of 444 firms and a total of 3717 firm-year observations that belong to eleven different industries as per Campbell's (1996) industry classification. ${ }^{11}$ To alleviate the impact of outliers on the analysis, we winsorize all firm-level variables at the 1st and 99th percentiles.

\footnotetext{
10 The choice of these ten countries is dictated by the availability of data in the Worldscope database. In fact, in many other countries of the region, there are only a few or no reported companies in the database, which led to their exclusion from our sample. ${ }^{11}$ Campbell (1996) classifies firms into 12 industries. We end up with 11 industries because we remove companies that belong to the finance industry.
} 
Table 1

Description of variables and sources.

\begin{tabular}{|c|c|c|}
\hline Variable & Description & Source \\
\hline \multicolumn{3}{|l|}{ Panel A: Variables used in the main analysis } \\
\hline Debt maturity (DMAT) & $\begin{array}{l}\text { The ratio of long-term debt (maturing more than } 1 \text { year) to total debt. Total } \\
\text { debt is the sum of long-term debt and debt in current liabilities. }\end{array}$ & Fitch-IBCA Worldscope, authors' calculations \\
\hline Leverage (LEV) & The ratio of total debt to total asset & Fitch-IBCA Worldscope. \\
\hline Size (SIZE) & The natural log of total assets & Fitch-IBCA Worldscope \\
\hline Growth opportunities (GROWTH) & The ratio of the market value of equity plus the book value of debt to total assets & Fitch-IBCA Worldscope, authors' calculations \\
\hline Tangibility (PPE) & The ratio of tangible assets (property, plant, and equipment) to total assets & Fitch-IBCA Worldscope \\
\hline Asset Maturity (AMAT) & $\begin{array}{l}\text { The weighted average of the maturity of long-term assets and current assets. } \\
\text { The maturity of long-term assets is calculated as the fixed asset (property, } \\
\text { plant, and equipment) divided by depreciation expenses. The maturity of } \\
\text { current assets is calculated as current assets divided by cost of goods sold. }\end{array}$ & Fitch-IBCA Worldscope, authors' calculations \\
\hline Distance from bankruptcy (Z-SCORE) & $\begin{array}{l}\text { Altman's Z-score calculated as: by Z-Score }=3.3 \text { (EBIT/total assets) }+1.0 \\
\text { (sales/total assets) }+1.4 \text { (retained earnings/total assets) }+1.2 \text { (working } \\
\text { capital/total assets) }\end{array}$ & Fitch-IBCA Worldscope, authors' calculations \\
\hline Profitability (ROA) & $\begin{array}{l}\text { Return on assets calculated as the ratio of EBIT plus depreciation expenses and } \\
\text { provisions to total equity to total assets }\end{array}$ & Fitch-IBCA Worldscope \\
\hline Effective Tax Rate (ETR) & The ratio of income taxes to pre-tax income. & Fitch-IBCA Worldscope, authors' calculations \\
\hline GDP growth (GDPG) & Growth rate of real of GDP & IMF's International Financial Statistics \\
\hline Inflation (INF) & Rate of increase in CPI & IMF's International Financial Statistics \\
\hline Access to financial intermediaries (FIND) & The ratio of domestic credit provided by financial sector to GDP & World Development Indicators \\
\hline Stock market development (SMD) & The ratio of market capitalization of listed companies to GDP & World Development Indicators \\
\hline Regulatory effectiveness (RE) & $\begin{array}{l}\text { Index reflects perceptions of the ability of the government to formulate and } \\
\text { implement sound regulations regarding the acquisition of property, licensing of } \\
\text { new businesses, hiring of workers, importing factors of production, exporting } \\
\text { output or capital, contracting with suppliers for needed inputs, payment of } \\
\text { taxes, government licenses and fees, and so forth. The index ranges from }-2.5 \\
\text { (weak effectiveness) to } 2.5 \text { (strong effectiveness). }\end{array}$ & Governance indicators database (World Bank) \\
\hline Rule of law (RL) & $\begin{array}{l}\text { Index reflects perceptions of the extent to which agents have confidence in and } \\
\text { abide by the rules of society, and in particular the quality of contract enforcement, } \\
\text { property rights, the police, and the courts, as well as the likelihood of crime and } \\
\text { violence. The index ranges from }-2.5 \text { (weak law) to } 2.5 \text { (strong law). }\end{array}$ & Governance indicators database (World Bank) \\
\hline Corruption (CORR) & $\begin{array}{l}\text { Index reflects perceptions of the extent to which public power is exercised for } \\
\text { private gain, including both petty and grand forms of corruption, as well as } \\
\text { "capture" of the state by elites and private interests. The index ranges from } \\
-2.5 \text { (weak control of corruption) to } 2.5 \text { (strong control of corruption). }\end{array}$ & Governance indicators database (World Bank) \\
\hline Credit right $(\mathrm{CR})$ & $\begin{array}{l}\text { This index measures the powers of secured lenders in bankruptcy. The index } \\
\text { ranges from } 0 \text { (poor creditor rights) and } 4 \text { (strong creditor rights). }\end{array}$ & Djankov et al. (2007) \\
\hline \multicolumn{3}{|c|}{ Panel B: Alternative debt maturity measure used in the robustness tests } \\
\hline Long-term liabilities to total liabilities (DMAT2) & $\begin{array}{l}\text { Alternative proxy for long-term debt calculated as the ratio of (Total liabilities } \\
\text { minus current liabilities) to total liabilities. }\end{array}$ & Fitch-IBCA Worldscope \\
\hline
\end{tabular}

This table provides descriptions of all variables used in the debt maturity analysis.

\subsection{Descriptive statistics}

Panel A of Table 2 presents descriptive statistics of DMAT by country whereas Panel B reports DMAT statistics by industry and Panel C reports descriptive statistics of DMAT for the full sample. Panel A suggests that there is a wide variation across the MENA region in the extent to which firms hold long-term debt in their books. The average DMAT ranges from a minimum of $3.64 \%$ (median: $2.78 \%$ ) in Bahrain to a maximum of $14.83 \%$ in Qatar (median: 6.85\%). Looking at the median suggests that the typical firm in Egypt has only $2.45 \%$ of its debt as long-term debt whereas in Oman, the country with the highest DMAT median, the typical firm has only $8.10 \%$ of its debt as long-term debt. A look at Panel A also reveals a large within-country variation in the use of long-term debt in the MENA region, with standard deviations of DMAT above $10 \%$ in all countries, except for Bahrain. Panel B of Table 2 shows that the typical firm has about $4 \%$ of its total debt with a long-term maturity no matter what industry it operates in. Panel C of Table 2 shows that the typical MENA firm raises only $3.41 \%$ of its debt with a long-term maturity. By way of comparison, the mean DMAT in any MENA country is lower than in any of the 42 countries reported in El Ghoul et al. (2014) for the 1994-2003 period and in any of the 30 countries reported in Demirgüç-Kunt and Maksimovic (1999) for the 1980-1991 period. Similarly, the DMAT median in any MENA country is lower than in any of the 39 countries reported in Fan et al. (2012) for the 1991-2006 period. In sum, MENA firms' reliance on long-term debt is much less important not only than firms located in developed countries but also compared to those located in developing countries reported in prior studies. Fig. 1 ranks our sample countries by the mean of DMAT and confirms the observation of the scarce use of long-term debt by MENA firms.

In Panel A of Table 3, we report summary statistics of our firm-level explanatory variables by country while in Panel B, we report the summary statistics for the full sample. Among others, Panel A shows that, on average, the largest and the smallest companies are located in the UAE and Jordan, respectively. It also shows that the most levered companies are located in Oman and the least are in Bahrain. Overall, the panel reveals a great deal of variation in firm-level characteristics across MENA countries. Additionally, Panel B shows high variability of firm characteristics in the whole region.

Table 4 reports summary statistics of country-level variables used to capture the institutional and macroeconomic environment. As regards public governance variables, Panel A shows that Morocco and Egypt have very low records of abidance by the rule of law as the RL score is negative in both countries. In the rest of the countries, RL is positive, yet low relative to the maximum of 2.5. Among all countries, Qatar and Bahrain score best in terms of rule of law. Again Morocco and Egypt are the worst in terms of authorities' regulatory effectiveness, with negative scores of RE. Bahrain and the UAE are the best in this regard. Consistent with their low record in terms of rule of law and regulatory effectiveness, Egypt and Morocco are the most corrupt countries 
Table 2

Summary statistics of debt maturity $(\%)$.

\begin{tabular}{|c|c|c|c|c|c|c|c|c|c|}
\hline & No. of firms & Observations & Mean & Stdev & Min & 25th percentile & Median & 75th percentile & Max \\
\hline \multicolumn{10}{|c|}{ Panel A: Debt maturity, by country } \\
\hline Bahrain & 18 & 162 & 3.638 & 4.779 & 0.000 & 1.536 & 2.781 & 26.065 & 31.209 \\
\hline Egypt & 93 & 837 & 9.270 & 13.447 & 0.941 & 1.651 & 2.454 & 40.654 & 94.626 \\
\hline Jordan & 79 & 711 & 7.229 & 10.831 & 0.000 & 2.258 & 4.914 & 29.589 & 93.077 \\
\hline Kuwait & 35 & 315 & 11.057 & 12.677 & 0.000 & 1.935 & 6.258 & 27.860 & 57.555 \\
\hline Morocco & 37 & 333 & 9.747 & 13.521 & 0.413 & 1.258 & 2.717 & 29.589 & 62.155 \\
\hline Oman & 62 & 558 & 14.499 & 17.797 & 0.000 & 2.734 & 8.105 & 28.800 & 84.478 \\
\hline Qatar & 16 & 144 & 14.832 & 17.744 & 0.207 & 3.206 & 6.852 & 41.642 & 68.420 \\
\hline Saudi Arabia & 55 & 495 & 7.675 & 12.004 & 0.000 & 1.595 & 4.676 & 23.629 & 60.717 \\
\hline Tunisia & 31 & 279 & 10.749 & 11.437 & 0.000 & 1.676 & 6.974 & 15.332 & 41.585 \\
\hline UAE & 18 & 162 & 9.206 & 11.458 & 1.001 & 3.974 & 5.536 & 20.541 & 51.361 \\
\hline \multicolumn{10}{|c|}{ Panel B: Debt maturity by industry } \\
\hline Petroleum/mining & 16 & 144 & 11.656 & 14.645 & 2.245 & 2.305 & 4.337 & 16.737 & 94.626 \\
\hline Consumer durables & 15 & 135 & 9.172 & 13.703 & 2.413 & 1.419 & 4.0255 & 16.806 & 75.453 \\
\hline Basic industry & 138 & 1242 & 10.684 & 15.951 & 0.207 & 1.871 & 3.852 & 16.429 & 75.816 \\
\hline Food & 75 & 648 & 11.279 & 14.960 & 1.561 & 1.032 & 3.689 & 15.102 & 91.421 \\
\hline Construction & 72 & 648 & 10.094 & 13.944 & 0.000 & 1.731 & 3.597 & 16.044 & 84.478 \\
\hline Capital good & 11 & 99 & 9.878 & 15.755 & 10.723 & 4.630 & 5.207 & 18.280 & 25.453 \\
\hline Transportation & 19 & 171 & 11.116 & 14.797 & 2.001 & 1.982 & 5.005 & 18.051 & 75.669 \\
\hline Utilities & 18 & 162 & 10.187 & 13.870 & 0.000 & 1.062 & 4.0778 & 16.196 & 85.453 \\
\hline Textile/trade & 8 & 72 & 8.367 & 15.118 & 0.000 & 0.832 & 3.939 & 16.453 & 63.530 \\
\hline Services & 38 & 342 & 9.187 & 15.547 & 0.000 & 2.562 & 3.923 & 28.648 & 66.928 \\
\hline Leisure & 34 & 306 & 9.150 & 15.952 & 0.000 & 2.344 & 4.623 & 25.879 & 69.084 \\
\hline Panel C: Full sample & 444 & 3717 & 10.07 & 13.743 & 0.000 & 1.508 & 3.416 & 25.060 & 94.626 \\
\hline
\end{tabular}

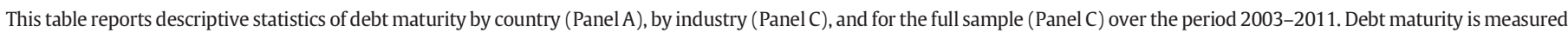
as the ratio of long-term debt (maturing in more than 1 year) to total debt. Total debt is the sum of long-term debt and debt in current liabilities.

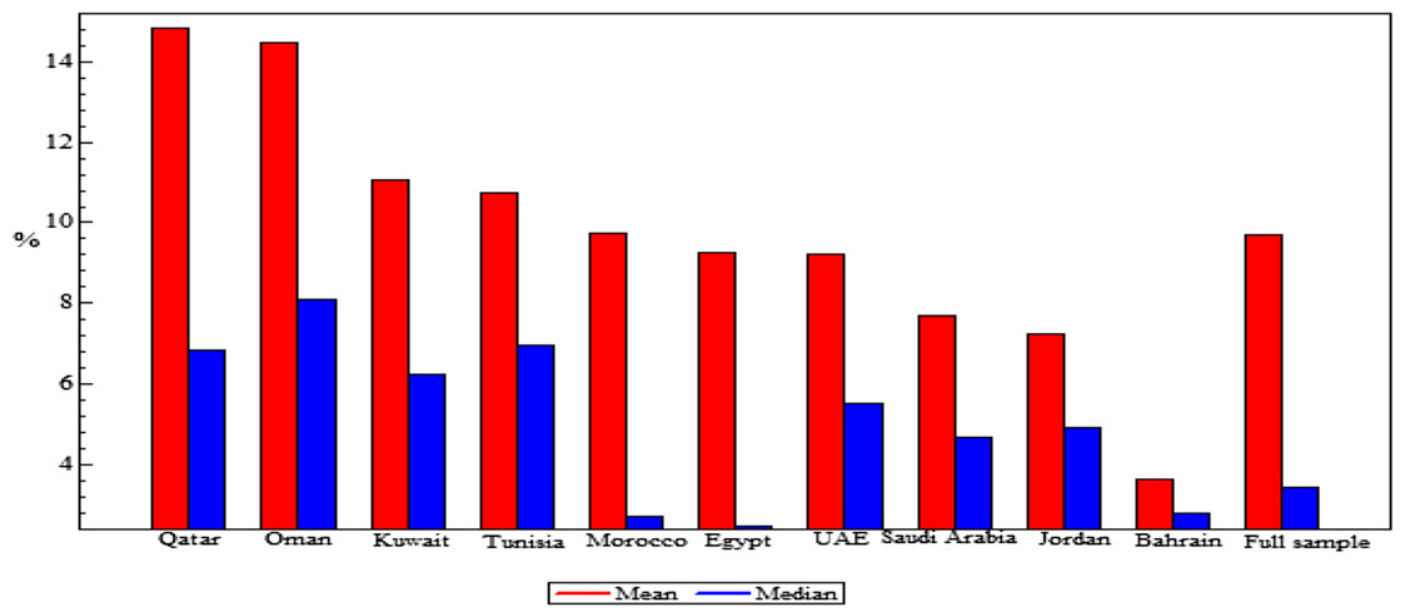

Fig. 1. Mean and median of debt maturity by country.

in our sample, with negative scores of CORR - indicating a low control of corruption. On the opposite side, the UAE and Qatar are the least corrupt countries. With respect to financial development, FIND varies from a minimum of $18.33 \%$ in Saudi Arabia to a maximum of $102.9 \%$ in Jordan while SMD varies from a minimum of $14 \%$ in Tunisia to a maximum of $177.5 \%$ in Jordan. The extent to which creditors are legally protected also varies from one country to another, with the CR score ranging between a minimum of zero (0) in Oman and Tunisia to a maximum of 3 in Kuwait and Saudi Arabia. In sum, although generally considered as a uniform block, MENA countries exhibit a great amount of variation with respect to the quality of their institutional frameworks, which may, in turn, influence the maturity structures of their firms' debt.

In Table 5, we report Pearson correlation coefficients between firmand country-level variables used in the debt maturity analysis. Consistent with prior findings and our predictions, we find that DMAT is positively and significantly correlated with LEV, SIZE, PPE, and AMAT. ${ }^{12}$ Likewise, in line with Flannery's (1986) signaling theory, ROA used as a proxy for firm quality, and in line with Kane et al.'s (1985) prediction, ETR used as a proxy for tax rates, are negatively correlated with DMAT. The sign of the correlation coefficient estimates on $\mathrm{MB}$ and Z-SCORE are however against theoretical predictions and to the opposite of our expectations. Among the institutional variables, DMAT is positively correlated with RE, RL, CR, and negatively correlated with CORR, consistent with our expectations. It is, however, negatively correlated with our two financial development measures. We also notice that the estimated correlation coefficients among the firm-level

\footnotetext{
12 We particularly notice here that the correlation coefficient between DMAT and LEV is moderate $(0.566)$, which indicates that long-term debt is not capturing the presence of debt in a firm's balance sheet.
} 
Table 3

Summary statistics of firm-level explanatory variables.

\begin{tabular}{|c|c|c|c|c|c|c|c|c|c|}
\hline & LEV & SIZE & GROWTH & PPE & AMAT & Z- SCORE & ROA & ETR & DMAT2 \\
\hline \multicolumn{10}{|c|}{ Panel A: Summary statistics (mean values) of firm-level explanatory variables, by country } \\
\hline Bahrain & 15.640 & 4.893 & 1.177 & 25.504 & 6.939 & 1.548 & 10.287 & 1.190 & 15.608 \\
\hline Egypt & 47.125 & 4.883 & 1.727 & 32.350 & 21.238 & 1.270 & 9.685 & 19.196 & 20.270 \\
\hline Jordan & 32.900 & 4.446 & 3.270 & 34.368 & 31.629 & 0.909 & 3.902 & 11.503 & 21.879 \\
\hline Kuwait & 42.218 & 5.589 & 0.945 & 18.524 & 13.870 & 0.918 & 6.402 & 2.070 & 36.645 \\
\hline Morocco & 45.607 & 5.102 & 1.915 & 34.303 & 11.971 & 1.687 & 12.458 & 26.785 & 22.892 \\
\hline Oman & 52.770 & 4.471 & 0.971 & 41.294 & 33.839 & 0.994 & 5.104 & -0.852 & 36.583 \\
\hline Qatar & 33.050 & 5.612 & 1.172 & 37.661 & 73.192 & 0.715 & 7.541 & 0.394 & 45.135 \\
\hline Saudi Arabia & 31.866 & 5.526 & 1.966 & 44.901 & 134.550 & 1.001 & 8.407 & 6.697 & 32.825 \\
\hline Tunisia & 38.722 & 4.674 & 1.388 & 28.565 & 5.198 & 1.444 & 8.434 & 11.800 & 24.284 \\
\hline UAE & 37.575 & 5.653 & 1.081 & 26.797 & 30.397 & 0.991 & 7.578 & 0.198 & 30.437 \\
\hline \multicolumn{10}{|c|}{ Panel B: Summary statistics of firm-level explanatory variables for the full sample } \\
\hline Mean & 40.507 & 4.914 & 1.845 & 34.637 & 42.774 & 1.099 & 7.256 & 9.628 & 27.402 \\
\hline Stdev & 27.559 & 0.796 & 15.955 & 25.527 & 62.272 & 1.122 & 11.249 & 1.838 & 26.214 \\
\hline Min & 0.000 & 2.841 & 0.004 & 0.003 & 0.987 & -9.858 & -77.18 & -39.50 & 2.119 \\
\hline 25th percentile & 15.812 & 5.160 & 0.520 & 5.827 & 2.478 & 0.599 & 3.265 & 2.018 & 8.335 \\
\hline Median & 37.266 & 4.837 & 0.899 & 31.283 & 15.573 & 1.104 & 6.450 & 7.320 & 20.590 \\
\hline 75th percentile & 55.294 & 6.180 & 1.459 & 39.960 & 7.660 & 1.373 & 11.30 & 9.532 & 26.662 \\
\hline Max & 97.172 & 7.928 & 540.972 & 94.804 & 233.3 & 7.135 & 80.16 & 60.619 & 100 \\
\hline
\end{tabular}

This table reports descriptive statistics of firm variables for the period 2003-2011. See Table 1 for detailed definitions of variables.

Table 4

Summary statistics of country-level variables.

\begin{tabular}{|c|c|c|c|c|c|c|c|c|}
\hline & RL & RE & CORR & FIND (\%) & SMD $(\%)$ & $\mathrm{CR}$ & GDPG (\%) & $\operatorname{INF}(\%)$ \\
\hline \multicolumn{9}{|c|}{ Panel A: Summary statistics (mean values) of country and institutional variables, by country } \\
\hline Bahrain & 0.630 & 0.741 & 0.330 & 58.076 & 97.292 & 1.000 & 2.200 & 2.300 \\
\hline Egypt & -0.054 & -0.345 & -0.570 & 88.337 & 62.761 & 2.000 & 5.300 & 9.900 \\
\hline Jordan & 0.389 & 0.284 & 0.305 & 102.926 & 177.485 & 1.000 & 6.300 & 4.900 \\
\hline Kuwait & 0.580 & 0.321 & 0.601 & 70.899 & 119.460 & 3.000 & 6.300 & 4.200 \\
\hline Morocco & -0.139 & -0.206 & -0.271 & 84.821 & 63.882 & 1.000 & 4.800 & 1.800 \\
\hline Oman & 0.560 & 0.611 & 0.367 & 33.591 & 36.516 & 0.000 & 4.400 & 3.900 \\
\hline Qatar & 0.693 & 0.394 & 0.987 & 53.472 & 118.811 & 1.000 & 15.200 & 6.400 \\
\hline Saudi Arabia & 0.146 & 0.079 & -0.112 & 18.330 & 98.465 & 3.000 & 4.000 & 3.500 \\
\hline Tunisia & 0.137 & 0.018 & -0.012 & 66.113 & 14.038 & 0.000 & 4.800 & 3.600 \\
\hline UAE & 0.458 & 0.621 & 1.031 & 61.627 & 36.196 & 2.000 & 4.900 & 8.400 \\
\hline \multicolumn{9}{|c|}{ Panel B: Summary statistics of country and institutional variables for full sample } \\
\hline Mean & 0.280 & 0.167 & 0.090 & 67.927 & 91.667 & 1.481 & 5.270 & 5.466 \\
\hline Stdev & 0.280 & 0.369 & 0.477 & 32.460 & 64.272 & 1.040 & 3.720 & 4.804 \\
\hline Min & -0.261 & -0.619 & -0.715 & 36.530 & 8.470 & 0.000 & -5.360 & -1.273 \\
\hline 25th percentile & 0.071 & -0.175 & -0.357 & 36.624 & 43.903 & 1.000 & 3.190 & 2.040 \\
\hline Median & 0.295 & 0.222 & 0.193 & 70.160 & 75.201 & 1.000 & 4.690 & 4.295 \\
\hline 75th percentile & 0.497 & 0.505 & 0.380 & 89.042 & 118.360 & 2.000 & 7.160 & 8.500 \\
\hline Max & 0.932 & 0.829 & 1.681 & 114.319 & 299.127 & 3.000 & 26.750 & 18.320 \\
\hline
\end{tabular}

This table reports descriptive statistics of country and institutional explanatory variables for the period 2003-2011. See Table 1 for detailed definitions of each variable.

variables and among the country-level variables which we include in the same regression equations are generally low, implying that multicollinearity is not a concern for our analyses.

\subsection{Empirical method}

We examine how well several firm and institutional factors explain corporate debt maturity in the MENA region using the following static panel data model $^{13}$ :

$\operatorname{DMAT}_{i, t}=\alpha+\beta X_{i, t}+\theta Z_{t}+\gamma_{s}+\varepsilon_{i, t}$

where the dependent variable, $D M A T_{i, t}$ is firm $i$ 's debt maturity at time $t, X_{i, t}$ is a vector of time-varying firm-specific variables, $Z_{t}$ is a set of

\footnotetext{
13 We model debt maturity in a static setting given the specific institutional environment in which MENA firms operate. Given this environment, we assume that adjustment in debt maturity structure is very slow - if at all - and that MENA firms remain with the same debt maturity structures long because of slow and little changes in the underlying factors.
}

country-level institutional and macroeconomic factors, and $\gamma_{i}$ is time-invariant unobserved firm-specific effects which capture firm heterogeneity and are time invariant; $\gamma_{s}$ are industry dummies to control for characteristics that are specific to an industry (i.e., market size, concentration, financial frictions, government intervention, and support). Finally, $\varepsilon_{i, t}$ is the regression composed error-term, which is time-varying and serially uncorrelated with mean zero and variance $\sigma^{2}$.

We estimate our DMAT regression equations using the random effects panel data estimation technique. The choice of the random effects method is appropriate for several reasons. First, by including individual effects, this method can control firm heterogeneity. Second, since all relevant determinants of debt maturity are included in the regression specification, it is assumed that a possible correlation between unobservable individual effects and the explanatory variables can be ignored (e.g., Affinito \& Tagliaferri, 2010), and thereby overcome the potential problem of serially correlated error. Third, the fact that some of our institutional variables are non-time-varying prohibits us from using fixed effect estimations (Wooldridge, 2002; 
Table 5

Pearson correlation coefficients.*

\begin{tabular}{|c|c|c|c|c|c|c|c|c|c|c|c|c|c|c|c|c|c|}
\hline & DMAT & LEV & SIZE & MB & PPE & AMAT & Z-Score & ROA & ETR & GDPG & INF & FIND & SMD & $\mathrm{RE}$ & RL & CORR & CR \\
\hline DMAT & 1.000 & & & & & & & & & & & & & & & & \\
\hline LEV & $\begin{array}{c}0.566^{*} \\
(0.000)\end{array}$ & 1.000 & & & & & & & & & & & & & & & \\
\hline SIZE & $\begin{array}{l}0.211^{*} \\
(0.000)\end{array}$ & $\begin{array}{c}0.171^{*} \\
(0.000)\end{array}$ & 1.000 & & & & & & & & & & & & & & \\
\hline MB & $\begin{array}{c}0.095^{*} \\
(0.000)\end{array}$ & $\begin{array}{c}0.217^{*} \\
(0.000)\end{array}$ & $\begin{array}{c}0.237^{*} \\
(0.000)\end{array}$ & 1.000 & & & & & & & & & & & & & \\
\hline PPE & $\begin{array}{c}0.249^{*} \\
(0.000)\end{array}$ & $\begin{array}{c}0.098^{*} \\
(0.000)\end{array}$ & $\begin{array}{c}0.028 \\
(0.090)\end{array}$ & $\begin{array}{c}0.064^{*} \\
(0.000)\end{array}$ & 1.000 & & & & & & & & & & & & \\
\hline AMAT & $\begin{array}{c}0.216^{*} \\
(0.000)\end{array}$ & $\begin{array}{c}-0.053^{*} \\
(0.005)\end{array}$ & $\begin{array}{c}0.072^{*} \\
(0.000)\end{array}$ & $\begin{array}{l}-0.013 \\
(0.504)\end{array}$ & $\begin{array}{l}0.532^{*} \\
(0.000)\end{array}$ & 1.000 & & & & & & & & & & & \\
\hline Z-Score & $\begin{array}{c}-0.322^{*} \\
(0.000)\end{array}$ & $\begin{array}{c}-0.195^{*} \\
(0.000)\end{array}$ & $\begin{array}{l}0.037^{*} \\
(0.028)\end{array}$ & $\begin{array}{l}0.039^{*} \\
(0.021)\end{array}$ & $\begin{array}{c}-0.217^{*} \\
(0.000)\end{array}$ & $\begin{array}{c}-0.430^{*} \\
(0.000)\end{array}$ & 1.000 & & & & & & & & & & \\
\hline ROA & $\begin{array}{c}-0.207^{*} \\
(0.000)\end{array}$ & $\begin{array}{c}-0.238^{*} \\
(0.000)\end{array}$ & $\begin{array}{c}0.215^{*} \\
(0.000)\end{array}$ & $\begin{array}{l}0.063^{*} \\
(0.000)\end{array}$ & $\begin{array}{c}-0.058^{*} \\
(0.000)\end{array}$ & $\begin{array}{c}-0.156^{*} \\
(0.000)\end{array}$ & $\begin{array}{l}0.743^{*} \\
(0.000)\end{array}$ & 1.000 & & & & & & & & & \\
\hline ETR & $\begin{array}{c}-0.071^{*} \\
(0.000)\end{array}$ & $\begin{array}{l}0.062^{*} \\
(0.000)\end{array}$ & $\begin{array}{c}0.120^{*} \\
(0.000)\end{array}$ & $\begin{array}{c}0.101^{*} \\
(0.000)\end{array}$ & $\begin{array}{l}0.036^{*} \\
(0.026)\end{array}$ & $\begin{array}{c}-0.135^{*} \\
(0.000)\end{array}$ & $\begin{array}{c}0.393^{*} \\
(0.000)\end{array}$ & $\begin{array}{c}0.373^{*} \\
(0.000)\end{array}$ & 1.000 & & & & & & & & \\
\hline GDPG & $\begin{array}{l}-0.017 \\
(0.340)\end{array}$ & $\begin{array}{c}-0.048^{*} \\
(0.003)\end{array}$ & $\begin{array}{c}-0.050^{*} \\
(0.002)\end{array}$ & $\begin{array}{c}-0.112^{*} \\
(0.000)\end{array}$ & $\begin{array}{l}-0.022 \\
(0.169)\end{array}$ & $\begin{array}{l}0.040^{*} \\
(0.035)\end{array}$ & $\begin{array}{c}0.031 \\
(0.073)\end{array}$ & $\begin{array}{l}0.075^{*} \\
(0.000)\end{array}$ & $\begin{array}{l}-0.004 \\
(0.788)\end{array}$ & & & & & & & & \\
\hline INF & $\begin{array}{l}-0.004 \\
(0.822)\end{array}$ & $\begin{array}{l}0.071^{*} \\
(0.000)\end{array}$ & $\begin{array}{l}0.069^{*} \\
(0.000)\end{array}$ & $\begin{array}{l}0.220^{*} \\
(0.000)\end{array}$ & $\begin{array}{c}-0.050^{*} \\
(0.002)\end{array}$ & $\begin{array}{l}0.048^{*} \\
(0.011)\end{array}$ & $\begin{array}{c}0.016 \\
(0.338)\end{array}$ & $\begin{array}{c}0.019 \\
(0.253)\end{array}$ & $\begin{array}{l}0.307^{*} \\
(0.000)\end{array}$ & $\begin{array}{c}0.032^{*} \\
(0.044)\end{array}$ & 1.0000 & & & & & & \\
\hline FIND & $\begin{array}{c}-0.036^{*} \\
(0.033)\end{array}$ & $\begin{array}{l}-0.008 \\
(0.624)\end{array}$ & $\begin{array}{c}-0.204^{*} \\
(0.000)\end{array}$ & $\begin{array}{c}-0.097^{*} \\
(0.000)\end{array}$ & $\begin{array}{c}-0.109^{*} \\
(0.000)\end{array}$ & $\begin{array}{l}-0.012 \\
(0.525)\end{array}$ & $\begin{array}{l}-0.004 \\
(0.837)\end{array}$ & $\begin{array}{c}-0.065^{*} \\
(0.000)\end{array}$ & $\begin{array}{l}0.2247^{*} \\
(0.000)\end{array}$ & $\begin{array}{c}0.014 \\
(0.389)\end{array}$ & $\begin{array}{c}0.187^{*} \\
(0.000)\end{array}$ & 1.000 & & & & & \\
\hline SMD & $\begin{array}{c}-0.119^{*} \\
(0.000)\end{array}$ & $\begin{array}{c}-0.208^{*} \\
(0.000)\end{array}$ & $\begin{array}{c}0.002 \\
(0.885)\end{array}$ & $\begin{array}{c}-0.055^{*} \\
(0.001)\end{array}$ & $\begin{array}{c}-0.046^{*} \\
(0.004)\end{array}$ & $\begin{array}{c}0.092^{*} \\
(0.000)\end{array}$ & $\begin{array}{c}-0.074^{*} \\
(0.000)\end{array}$ & $\begin{array}{c}-0.035^{*} \\
(0.029)\end{array}$ & $\begin{array}{c}0.326^{*} \\
(0.000)\end{array}$ & $\begin{array}{c}-0.103^{*} \\
(0.000)\end{array}$ & $\begin{array}{c}-0.063^{*} \\
(0.000)\end{array}$ & $\begin{array}{c}0.441^{*} \\
(0.000)\end{array}$ & 1.000 & & & & \\
\hline $\mathrm{RE}$ & $\begin{array}{l}0.023^{*} \\
(0.004)\end{array}$ & $\begin{array}{c}0.085^{*} \\
(0.000)\end{array}$ & $\begin{array}{c}-0.117^{*} \\
(0.000)\end{array}$ & $\begin{array}{c}-0.041^{*} \\
(0.010)\end{array}$ & $\begin{array}{l}-0.010 \\
(0.556)\end{array}$ & $\begin{array}{c}-0.047^{*} \\
(0.013)\end{array}$ & $\begin{array}{c}-0.117^{*} \\
(0.000)\end{array}$ & $\begin{array}{c}-0.119^{*} \\
(0.000)\end{array}$ & $\begin{array}{c}0.013 \\
(0.394)\end{array}$ & $\begin{array}{c}-0.288^{*} \\
(0.000)\end{array}$ & $\begin{array}{c}-0.208^{*} \\
(0.000)\end{array}$ & $\begin{array}{c}-0.315^{*} \\
(0.000)\end{array}$ & $\begin{array}{c}0.014 \\
(0.379)\end{array}$ & 1.000 & & & \\
\hline RL & $\begin{array}{l}0.039^{*} \\
(0.023)\end{array}$ & $\begin{array}{l}0.069^{*} \\
(0.000)\end{array}$ & $\begin{array}{c}-0.079^{*} \\
(0.000)\end{array}$ & $\begin{array}{c}-0.082^{*} \\
(0.000)\end{array}$ & $\begin{array}{c}-0.052^{*} \\
(0.001)\end{array}$ & $\begin{array}{c}-0.039^{*} \\
(0.037)\end{array}$ & $\begin{array}{c}-0.161^{*} \\
(0.000)\end{array}$ & $\begin{array}{c}-0.138^{*} \\
(0.000)\end{array}$ & $\begin{array}{c}0.033^{*} \\
(0.037)\end{array}$ & $\begin{array}{c}-0.336^{*} \\
(0.000)\end{array}$ & $\begin{array}{c}-0.171^{*} \\
(0.000)\end{array}$ & $\begin{array}{c}-0.194^{*} \\
(0.000)\end{array}$ & $\begin{array}{l}0.092^{*} \\
(0.000)\end{array}$ & $\begin{array}{c}0.864^{*} \\
(0.000)\end{array}$ & 1.000 & & \\
\hline CORR & $\begin{array}{c}-0.056^{*} \\
(0.001)\end{array}$ & $\begin{array}{c}-0.088^{*} \\
(0.000)\end{array}$ & $\begin{array}{l}-0.028 \\
(0.088)\end{array}$ & $\begin{array}{c}-0.088^{*} \\
(0.000)\end{array}$ & $\begin{array}{c}-0.070^{*} \\
(0.000)\end{array}$ & $\begin{array}{c}-0.077^{*} \\
(0.000)\end{array}$ & $\begin{array}{c}-0.150^{*} \\
(0.000)\end{array}$ & $\begin{array}{c}-0.129^{*} \\
(0.000)\end{array}$ & $\begin{array}{c}0.105^{*} \\
(0.000)\end{array}$ & $\begin{array}{c}-0.319^{*} \\
(0.000)\end{array}$ & $\begin{array}{c}-0.201^{*} \\
(0.000)\end{array}$ & $\begin{array}{c}-0.126^{*} \\
(0.000)\end{array}$ & $\begin{array}{c}0.132^{*} \\
(0.000)\end{array}$ & $\begin{array}{c}-0.840^{*} \\
(0.000)\end{array}$ & $\begin{array}{c}-0.887^{*} \\
(0.000)\end{array}$ & 1.000 & \\
\hline CR & $\begin{array}{l}0.077^{*} \\
(0.000)\end{array}$ & $\begin{array}{l}0.053^{*} \\
(0.001)\end{array}$ & $\begin{array}{c}0.462^{*} \\
(0.000)\end{array}$ & $\begin{array}{l}0.083^{*} \\
(0.000)\end{array}$ & $\begin{array}{c}-0.052^{*} \\
(0.001)\end{array}$ & $\begin{array}{l}0.107^{*} \\
(0.000)\end{array}$ & $\begin{array}{l}0.034^{*} \\
(0.045)\end{array}$ & $\begin{array}{l}0.088^{*} \\
(0.000)\end{array}$ & $\begin{array}{c}0.031 \\
(0.050)\end{array}$ & $\begin{array}{l}-0.017 \\
(0.292)\end{array}$ & $\begin{array}{l}0.180^{*} \\
(0.000)\end{array}$ & $\begin{array}{c}-0.038^{*} \\
(0.017)\end{array}$ & $\begin{array}{l}0.270^{*} \\
(0.000)\end{array}$ & $\begin{array}{l}0.467^{*} \\
(0.000)\end{array}$ & $\begin{array}{l}0.332^{*} \\
(0.000)\end{array}$ & $\begin{array}{c}-0.286^{*} \\
(0.000)\end{array}$ & 1.000 \\
\hline
\end{tabular}

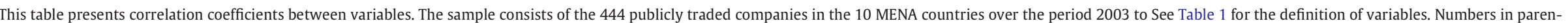
theses indicate p- values.

* Significance at $5 \%$ level or less. 
Bell \& Jones, 2015). ${ }^{14}$ Fourth, fixed effects estimations require a very high number of periods, thereby may introduce incidental parameters' bias in the coefficients. Finally, the selection of a random effects estimation method is in line with the majority of related studies and therefore allows for a better comparison between our empirical results and those of the existing literature.

\section{Empirical evidence}

To examine the determinants of corporate debt maturity in the MENA region, we use our sample of 3717 firm-years from 10 countries over the 2003-2011 period. We start the analysis by documenting the effect of firm-level factors on debt maturity in a country-by-country setting (Section 4.1). We, next, pool observations from all countries together and include the set of country-level factors in the regression model to estimate their impact on debt maturity (Section 4.2).

We estimate our DMAT regression equations using the random effects panel data model. In Section 4.3, we check the robustness of our results to the use of alternative estimation methods and measures of debt maturity.

\subsection{Firm-level determinants of debt maturity}

Table 6 reports the results of country-by-country regressions of DMAT on firm-specific variables using the random effects method. All our regressions include industry dummies and year dummies to account for the potential effect of industry characteristics and time on the fraction of long-term debt in a firm's debt capital. We first notice that most firm-level variables selected based on prior research on debt maturity in other geographical regions and countries generally load statistically significant with the predicted signs in most of the MENA countries. The use of long-term debt by firms located in MENA countries seems to respond to the same firm-level factors as those identified for firms operating in other countries all over the world. ${ }^{15}$ Specifically, we find that long-term debt is used more by more levered firms; the coefficient estimate on leverage (LEV) is positive and significant at least at the $5 \%$ level in each of our sample countries. This finding suggests that MENA firms with greater capacity to borrow are also more able to borrow with long-term maturity. It is also consistent with extant U.S. (e.g., Johnson, 2003; Custódio et al., 2013) and international empirical evidence (e.g., Giannetti, 2003; Zheng et al., 2012).

Consistent with prior literature (e.g., Barclay \& Smith, 1995; Demirgüç-Kunt \& Maksimovic, 1999; Fan et al., 2012), SIZE appears with a positive and significant coefficient estimate in eight of the ten MENA countries, suggesting that in most of the region's countries being a large company offers better chances to access long-term debt compared to a small company. Assuming that MENA-based firms gain in information transparency as they grow larger, this finding is consistent with adverse selection models predicting that firms select debt maturity structures that reduce the impact of information asymmetry on their cost of financing; smaller firms that suffer more from information asymmetry issue more of the less adverse selection-prone short-term debt. It is also a reasonable finding in the MENA region as small companies are perceived by financiers - mainly banks - as more risky and may thereby be screened out of the long-term debt market.

Although GROWTH loads negative in most of the sample countries, it is however significant only in two countries: in Egypt at the 10\% level and in Saudi Arabia at the 5\% level. In these two countries, firms with more growth opportunities raise more short-term debt possibly to mitigate the underinvestment problem (Myers, 1977). In the other

\footnotetext{
14 Wooldridge (2002) shows that fixed effects models cannot include time-constant factors as independent variables because there is no way to distinguish the effects of timeinvariant explanatory variables from the time-constant unobservable fixed effects.

15 Notice that most of the variables load with the same signs across most of the countries, though significance of some variables varies from one country to another.
}

countries, however, growth opportunities seem to be irrelevant to the debt maturity decision. One reasonable interpretation of this irrelevance is that because debt holders in the MENA region are mostly banks rather than bondholders, the debt holder-stockholder agency conflict of high-growth firms is mitigated by means other than shortening the term-to-maturity of debt. Specifically, with better access to information and closer follow-up of firms' activities, banks can negotiate and enforce strict covenants that reduce the underinvestment risk. This may, in turn, reduce the need for short-term debt as a tool used to mitigate the underinvestment risk of high-growth firms.

Consistent with the theoretical view that firms with more tangible assets can raise more long-term debt (e.g., Hart \& Moore, 1994; Myers \& Rajan, 1998), we find a positive and significant association between PPE - our measure of asset tangibility - and DMAT in seven of our sample countries. Qian and Strahan (2007), Kirch and Terra (2012), and Fan et al. (2012) report similar results on the association between asset tangibility and debt maturity. Our finding also confirms the fact - discussed earlier - that access to credit in MENA countries is contingent on the availability of collateral. Specifically, we find that access to long-term debt improves with the availability of tangible assets. This is a reasonable finding in the MENA context where legal frameworks of secured transactions allow for only a limited range of assets that can be used as collateral.

While positive in nine of ten countries, the coefficient estimate on AMAT is significant at the $5 \%$ level only in Bahrain, Morocco, and Qatar, implying that in these three countries, firms match the maturities of their borrowings with the durations of their assets. In step with prior literature (e.g., Guedes \& Oplar, 1996; Custódio et al., 2013), we report a positive and significant association between our measure of default risk - Z-SCORE - and debt maturity in seven out of the ten sample countries, indicating that the lower the default risk a firm faces (higher Z-SCORE) the greater is its long-term borrowing capacity, ceteris paribus. This is a much expected result in the MENA region where most countries suffer from deficient bankruptcy regimes that cause substantial losses on lenders in case of borrower default. In such a context, it is reasonable that banks look closely at firms' default risks before deciding to extend long-term credit.

Consistent with the signaling hypothesis of debt maturity, we find that firms with greater ROA - a proxy for the quality of projects - in Saudi Arabia and Qatar issue more short-term debt, possibly to signal good quality projects. However, the ROA-DMAT relation is not significant in the other eight countries. This is not a surprising finding in the MENA region since, as emphasized in our discussion of the region's financial systems, public corporate debt markets play only a very limited role whereas banks represent the main source of finance for firms. Accordingly, firms may not need debt maturity to signal their quality as they deal more with banks which, contrary to public markets, have better access to private information. Our proxy for tax rates, ETR, loads positive and significant at least at the $5 \%$ level in six of our sample countries. It is, however, insignificant in Kuwait, Morocco, Qatar, and the UAE. While the result in Morocco is surprising, it is nevertheless much expected in the richest Gulf countries - Qatar, Kuwait, and the UAE known for their loose tax systems. Overall, most firm-level variables seem to affect debt maturity in similar ways across many of the MENA countries. While this may seem odd given that economic structures vary across countries, especially between GCC-oil-exporting countries and the others - Egypt, Jordan, Morocco, and Tunisia, this finding may however reflect similarities in institutional frameworks, which lead to similar responses from firms and banks when it comes to debt maturity structures. We now turn to the impact of institutional quality on corporate debt maturity.

\subsection{Country-level determinants of debt maturity}

In this section, we estimate the influence of institutional quality on firm debt maturity in the MENA region. To this end, we pool all 
Table 6

Firm-specific determinants of debt maturity, by country.

\begin{tabular}{|c|c|c|c|c|c|c|c|c|c|c|}
\hline \multirow[t]{2}{*}{ Variable } & \multicolumn{10}{|l|}{ Country } \\
\hline & Bahrain & Egypt & Jordan & Kuwait & Morocco & Oman & Qatar & Saudi Arabia & Tunisia & UAE \\
\hline LEV & $\begin{array}{l}0.244^{* * * *} \\
(0.000)\end{array}$ & $\begin{array}{l}0.395^{* * *} \\
(0.000)\end{array}$ & $\begin{array}{l}0.142^{* * *} \\
(0.000)\end{array}$ & $\begin{array}{l}0.129^{* *} \\
(0.021)\end{array}$ & $\begin{array}{l}0.408^{* * * *} \\
(0.000)\end{array}$ & $\begin{array}{l}0.389^{* * *} \\
(0.000)\end{array}$ & $\begin{array}{l}0.451^{* * *} \\
(0.000)\end{array}$ & $\begin{array}{l}0.292^{* * *} \\
(0.000)\end{array}$ & $\begin{array}{l}0.407^{* * * *} \\
(0.000)\end{array}$ & $\begin{array}{l}0.273^{* * *} \\
(0.000)\end{array}$ \\
\hline SIZE & $\begin{array}{l}0.842^{*} \\
(0.067)\end{array}$ & $\begin{array}{l}0.166^{* *} \\
(0.035)\end{array}$ & $\begin{array}{l}0.927^{* * *} \\
(0.000)\end{array}$ & $\begin{array}{l}0.328^{*} \\
(0.055)\end{array}$ & $\begin{array}{l}0.079 \\
(0.563)\end{array}$ & $\begin{array}{l}0.261^{* *} \\
(0.049)\end{array}$ & $\begin{array}{l}0.854^{* *} \\
(0.044)\end{array}$ & $\begin{array}{l}0.354^{* * *} \\
(0.000)\end{array}$ & $\begin{array}{l}0.969^{*} \\
(0.078)\end{array}$ & $\begin{array}{l}-0.220 \\
(0.820)\end{array}$ \\
\hline GROWTH & $\begin{array}{l}-0.896 \\
(0.210)\end{array}$ & $\begin{array}{l}-0.093^{*} \\
(0.096)\end{array}$ & $\begin{array}{l}-0.009 \\
(0.415)\end{array}$ & $\begin{array}{l}-0.107 \\
(0.332)\end{array}$ & $\begin{array}{l}0.082 \\
(0.562)\end{array}$ & $\begin{array}{l}-0.246 \\
(0.760)\end{array}$ & $\begin{array}{l}-0.760 \\
(0.474)\end{array}$ & $\begin{array}{l}-0.279^{* *} \\
(0.014)\end{array}$ & $\begin{array}{l}-0.382 \\
(0.410)\end{array}$ & $\begin{array}{l}0.106 \\
(0.119)\end{array}$ \\
\hline PPE & $\begin{array}{l}0.047 \\
(0.283)\end{array}$ & $\begin{array}{l}0.052 \\
(0.132)\end{array}$ & $\begin{array}{l}0.076^{* * *} \\
(0.001)\end{array}$ & $\begin{array}{l}0.179^{* * *} \\
(0.002)\end{array}$ & $\begin{array}{l}0.217^{* * *} \\
(0.000)\end{array}$ & $\begin{array}{l}0.286^{* * *} \\
(0.000)\end{array}$ & $\begin{array}{l}0.164^{* *} \\
(0.050)\end{array}$ & $\begin{array}{l}0.052^{* *} \\
(0.012)\end{array}$ & $\begin{array}{l}0.175^{* *} \\
(0.014)\end{array}$ & $\begin{array}{l}0.006 \\
(0.148)\end{array}$ \\
\hline AMAT & $\begin{array}{l}0.181^{* *} \\
(0.017)\end{array}$ & $\begin{array}{l}0.000 \\
(0.901)\end{array}$ & $\begin{array}{l}0.001 \\
(0.791)\end{array}$ & $\begin{array}{l}0.013 \\
(0.507)\end{array}$ & $\begin{array}{l}0.118^{* *} \\
(0.020)\end{array}$ & $\begin{array}{l}-0.003 \\
(0.213)\end{array}$ & $\begin{array}{l}0.009^{* *} \\
(0.023)\end{array}$ & $\begin{array}{l}0.000 \\
(0.849)\end{array}$ & $\begin{array}{l}0.087 \\
(0.478)\end{array}$ & $\begin{array}{l}6.504 \\
(0.010)\end{array}$ \\
\hline Z-SCORE & $\begin{array}{l}0.320^{* *} \\
(0.035)\end{array}$ & $\begin{array}{l}0.225^{* *} \\
(0.010)\end{array}$ & $\begin{array}{l}0.077 \\
(0.143)\end{array}$ & $\begin{array}{l}0.793^{* *} \\
(0.042)\end{array}$ & $\begin{array}{l}0.629^{* *} \\
(0.041)\end{array}$ & $\begin{array}{l}0.426^{*} \\
(0.067)\end{array}$ & $\begin{array}{l}0.504^{* * *} \\
(0.042)\end{array}$ & $\begin{array}{l}0.086 \\
(0.116)\end{array}$ & $\begin{array}{l}0.667^{* *} \\
(0.016)\end{array}$ & $\begin{array}{c}-0.255 \\
(0.116)\end{array}$ \\
\hline ROA & $\begin{array}{l}0.018 \\
(0.855)\end{array}$ & $\begin{array}{l}0.156 \\
(0.141)\end{array}$ & $\begin{array}{l}-0.004 \\
(0.941)\end{array}$ & $\begin{array}{c}-0.076 \\
(0.442)\end{array}$ & $\begin{array}{l}-0.066 \\
(0.641)\end{array}$ & $\begin{array}{l}0.019 \\
(0.847)\end{array}$ & $\begin{array}{l}-0.287^{* * *} \\
(0.004)\end{array}$ & $\begin{array}{l}-0.095^{*} \\
(0.062)\end{array}$ & $\begin{array}{l}0.036 \\
(0.827)\end{array}$ & $\begin{array}{c}-0.329 \\
(0.597)\end{array}$ \\
\hline ETR & $\begin{array}{l}0.842^{* *} \\
(0.012)\end{array}$ & $\begin{array}{l}0.390^{* * * *} \\
(0.004)\end{array}$ & $\begin{array}{l}0.620^{* * *} \\
(0.006)\end{array}$ & $\begin{array}{l}6.814 \\
(0.164)\end{array}$ & $\begin{array}{l}0.064 \\
(0.961)\end{array}$ & $\begin{array}{l}0.310^{* * * *} \\
(0.000)\end{array}$ & $\begin{array}{l}-0.345 \\
(0.322)\end{array}$ & $\begin{array}{l}0.652^{* * *} \\
(0.046)\end{array}$ & $\begin{array}{l}0.007^{* *} \\
(0.040)\end{array}$ & $\begin{array}{l}-0.891 \\
(0.135)\end{array}$ \\
\hline Intercept & $\begin{array}{l}-0.348 \\
(0.690)\end{array}$ & $\begin{array}{l}-0.645^{* *} \\
(0.021)\end{array}$ & $\begin{array}{l}-0.947^{* *} \\
(0.040)\end{array}$ & $\begin{array}{l}-0.710^{* *} \\
(0.043)\end{array}$ & $\begin{array}{l}-0.422 \\
(0.150)\end{array}$ & $\begin{array}{l}-0.329 \\
(0.151)\end{array}$ & $\begin{array}{l}-0.344 \\
(0.322)\end{array}$ & $\begin{array}{l}-0.506^{* * *} \\
(0.000)\end{array}$ & $\begin{array}{l}-0.679 \\
(0.498)\end{array}$ & $\begin{array}{l}-0.177 \\
(0.161)\end{array}$ \\
\hline Adjusted $\mathrm{R}^{2}$ & 0.572 & 0.494 & 0.265 & 0.401 & 0.497 & 0.647 & 0.607 & 0.585 & 0.538 & 0.300 \\
\hline Wald test & $\begin{array}{l}66.83^{* * *} \\
(0.000)\end{array}$ & $\begin{array}{l}315.43^{* * *} \\
(0.000)\end{array}$ & $\begin{array}{l}116.99^{* * *} \\
(0.000)\end{array}$ & $\begin{array}{l}47.59^{* * *} \\
(0.000)\end{array}$ & $\begin{array}{l}105.96^{* * * *} \\
(0.000)\end{array}$ & $\begin{array}{l}583.99^{* * *} \\
(0.000)\end{array}$ & $\begin{array}{l}768.95^{* * *} \\
(0.000)\end{array}$ & $\begin{array}{l}460.60^{* * * *} \\
(0.000)\end{array}$ & $\begin{array}{l}266.28^{* * *} \\
(0.000)\end{array}$ & $\begin{array}{l}29.15^{* * *} \\
(0.000)\end{array}$ \\
\hline Industry effect & Yes & Yes & Yes & Yes & Yes & Yes & Yes & Yes & Yes & Yes \\
\hline Year effect & Yes & Yes & Yes & Yes & Yes & Yes & Yes & Yes & Yes & Yes \\
\hline Observations & 162 & 837 & 711 & 315 & 333 & 558 & 144 & 495 & 279 & 162 \\
\hline Firms & 18 & 93 & 79 & 35 & 37 & 62 & 16 & 55 & 31 & 18 \\
\hline
\end{tabular}

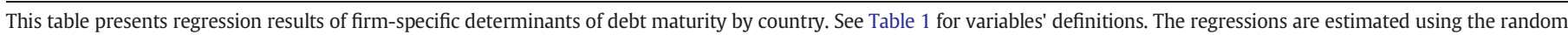
effects panel method. Numbers in parentheses indicate p- values.

* Significance at $10 \%$ level.

** Significance at the $5 \%$ level.

*** Significance at the $1 \%$ level.

observations and regress DMAT on our firm-level variables augmented with country-level institutional measures. Results are reported in Table 7. In model (1), we estimate the DMAT model including only the firm-level variables. Results reinforce our findings in the country-bycountry analysis, reported in Table 6; LEV, SIZE, PPE, Z-SCORE, and ETR load positive and significant at least at the $5 \%$ level, suggesting that MENA firms use more long-term debt as they become more indebted, grow larger, possess more tangible assets, face lower default risk, and are subject to higher tax rates. We also notice that these results are consistent across the seven models reported in Table 7, implying that no matter what additional country-level variables we add to the DMAT model, these firm-level factors continue to positively impact debt maturity. ${ }^{16}$

In model (2), in addition to the firm-level variables, we include two macroeconomic variables - GDP growth rate (GDPG) and inflation rate (INF) - to control for the potential impact of macroeconomic factors on firm debt maturity. We find that only GDPG loads positive and significant at the $10 \%$ level, suggesting that firm debt maturity is longer in countries with higher economic growth. In model (3), we further include our two measures of financial sector development: FIND and SMD. Only FIND, which is a proxy for the availability of credit through financial intermediaries, is positively and significantly associated with DMAT at the $1 \%$ level, implying that firms operating in countries with more developed financial intermediaries use more long-term debt. ${ }^{17}$ As much as economic magnitude is concerned, the coefficient on

\footnotetext{
${ }^{16}$ We also check the robustness of our analyses to the exclusion of firm-observations with zero long-term debt. To this end, we re-run the same model specifications as in Table 7 using a sample that excludes firm-observations with no long-term debt. This modified sample contains 397 firms with 3573 observations and accounts for about $90 \%$ of our original sample. The (unreported) results are qualitatively similar to those discussed in the paper.

17 We also use two alternative proxies for stock market development, which are the turnover ratio measured as the total value of traded shares during the year over the average market capitalization of the same year and the stocks traded-to-GDP calculated as the value of traded stocks to GDP in a giver year. With these measure, SMD continues to load insignificant.
}

FIND estimated in model (3) indicates that a $1 \%$ increase in FIND increases firm long-term debt by $3.6 \%$, which is important given the sample's mean DMAT of $9.70 \%$ reported in Table $2 .^{18}$ The FIND-DMAT positive association which holds across the remaining models reported in Table 7 suggests that firms' access to long term funding depends upon development of the financial system, especially financial intermediaries. ${ }^{19}$ MENA countries would, hence, gain in terms of their firms' access to longterm debt, which is a more stable source of capital, by enacting and implementing reforms aimed at fostering their financial sectors.

Columns (4), (5), and (6) include separately our three measures of the quality of public governance in MENA countries to avoid multicollinearity. In column (4), RL, which is a proxy for a country's strength of the rule of law loads positive, but statistically insignificant. In column (5), we estimate a positive and significant association between RE, a measure of regulatory effectiveness, and DMAT; the coefficient estimate on RE is positive and significant at the $5 \%$ level. This finding indicates that the better the quality of a country's public governance, especially with respect to effectiveness in legislating and implementing laws and regulations that enhance the business environment, the more long-term debt firms can get. In column (6), we include CORR to test for the potential effect of corruption on firm debt maturity. The result suggests that the less corrupt a country is (higher CORR) and the more short-term debt is used by its firms, possibly reflecting firms' difficult access to long-term debt by means other than corruption in low-quality institutional environments such as those prevailing in most MENA countries.

\footnotetext{
18 Our results are qualitatively the same using an alternative proxy for financial intermediation, which is the ratio of private credit to GDP.

${ }^{19}$ In an unreported result for the sake of space, we find that FIND continues to load positive and significant at the $1 \%$ level when we estimate the DMAT model excluding SMD. Moreover, the fact that the positive and significant association between FIND and DMAT holds across columns (4) - (7) suggests that the FIND-DMAT association documented in column (3) is not due to potential collinearity between FIND and SMD.
} 
Table 7

Firm- and country- level determinates of debt maturity.

\begin{tabular}{|c|c|c|c|c|c|c|c|}
\hline Variable & (1) & (2) & (3) & (4) & (5) & (6) & (7) \\
\hline LEV & $\begin{array}{l}0.353^{* * * *} \\
(0.000)\end{array}$ & $\begin{array}{l}0.353^{* * *} \\
(0.000)\end{array}$ & $\begin{array}{l}0.356^{* * *} \\
(0.000)\end{array}$ & $\begin{array}{l}0.356^{* * *} \\
(0.000)\end{array}$ & $\begin{array}{l}0.356^{* * *} \\
(0.000)\end{array}$ & $\begin{array}{l}0.358^{* * * *} \\
(0.000)\end{array}$ & $\begin{array}{l}0.354^{\text {*** }} \\
(0.000)\end{array}$ \\
\hline SIZE & $\begin{array}{l}0.870^{* *} \\
(0.047)\end{array}$ & $\begin{array}{l}0.944^{* *} \\
(0.048)\end{array}$ & $\begin{array}{l}0.822^{* *} \\
(0.032)\end{array}$ & $\begin{array}{l}0.825^{* *} \\
(0.047)\end{array}$ & $\begin{array}{l}0.899^{* *} \\
(0.033)\end{array}$ & $\begin{array}{l}0.756^{* *} \\
(0.044)\end{array}$ & $\begin{array}{l}0.711^{* *} \\
(0.047)\end{array}$ \\
\hline GROWTH & $\begin{array}{l}-0.020 \\
(0.146)\end{array}$ & $\begin{array}{l}-0.019 \\
(0.165)\end{array}$ & $\begin{array}{l}-0.018 \\
(0.189)\end{array}$ & $\begin{array}{l}-0.017 \\
(0.194)\end{array}$ & $\begin{array}{l}-0.018 \\
(0.185)\end{array}$ & $\begin{array}{l}-0.018 \\
(0.198)\end{array}$ & $\begin{array}{l}-0.018 \\
(0.193)\end{array}$ \\
\hline PPE & $\begin{array}{l}0.125^{* * *} \\
(0.000)\end{array}$ & $\begin{array}{l}0.124^{* * * *} \\
(0.000)\end{array}$ & $\begin{array}{l}0.121^{* * * *} \\
(0.000)\end{array}$ & $\begin{array}{l}0.120^{* * * *} \\
(0.000)\end{array}$ & $\begin{array}{l}0.120^{* * * *} \\
(0.000)\end{array}$ & $\begin{array}{l}0.123^{* * *} \\
(0.000)\end{array}$ & $\begin{array}{l}0.120^{* * * *} \\
(0.000)\end{array}$ \\
\hline AMAT & $\begin{array}{l}0.000 \\
(0.973)\end{array}$ & $\begin{array}{l}0.000 \\
(0.954)\end{array}$ & $\begin{array}{l}0.000 \\
(0.968)\end{array}$ & $\begin{array}{l}0.0000 \\
(0.969)\end{array}$ & $\begin{array}{l}0.000 \\
(0.974)\end{array}$ & $\begin{array}{l}0.000 \\
(0.965)\end{array}$ & $\begin{array}{l}0.000 \\
(0.988)\end{array}$ \\
\hline Z-SCORE & $\begin{array}{l}0.677^{* *} \\
(0.012)\end{array}$ & $\begin{array}{l}0.642^{* *} \\
(0.014)\end{array}$ & $\begin{array}{l}0.604^{* *} \\
(0.016)\end{array}$ & $\begin{array}{l}0.647^{* *} \\
(0.013)\end{array}$ & $\begin{array}{l}0.644^{* *} \\
(0.014)\end{array}$ & $\begin{array}{l}0.617^{* *} \\
(0.016)\end{array}$ & $\begin{array}{l}0.707^{* *} \\
(0.011)\end{array}$ \\
\hline ROA & $\begin{array}{l}0.017 \\
(0.635)\end{array}$ & $\begin{array}{l}0.015 \\
(0.678)\end{array}$ & $\begin{array}{l}0.012 \\
(0.736)\end{array}$ & $\begin{array}{l}0.017 \\
(0.632)\end{array}$ & $\begin{array}{l}0.017 \\
(0.630)\end{array}$ & $\begin{array}{l}0.020 \\
(0.569)\end{array}$ & $\begin{array}{l}0.016 \\
(0.665)\end{array}$ \\
\hline ETR & $\begin{array}{l}0.576^{\text {**** }} \\
(0.000)\end{array}$ & $\begin{array}{l}0.568^{* * * *} \\
(0.000)\end{array}$ & $\begin{array}{l}0.570^{* * * *} \\
(0.000)\end{array}$ & $\begin{array}{l}0.568^{* * * *} \\
(0.000)\end{array}$ & $\begin{array}{l}0.568^{* * *} \\
(0.000)\end{array}$ & $\begin{array}{l}0.561^{* * *} \\
(0.000)\end{array}$ & $\begin{array}{l}0.569^{* * *} \\
(0.000)\end{array}$ \\
\hline GDPG & & $\begin{array}{l}0.209^{*} \\
(0.072)\end{array}$ & $\begin{array}{l}0.304 \\
(0.868)\end{array}$ & $\begin{array}{l}0.172 \\
(0.977)\end{array}$ & $\begin{array}{l}0.551 \\
(0.928)\end{array}$ & $\begin{array}{l}2.080 \\
(0.733)\end{array}$ & $\begin{array}{l}0.898 \\
(0.882)\end{array}$ \\
\hline INF & & $\begin{array}{l}-0.633 \\
(0.131)\end{array}$ & $\begin{array}{l}-0.712^{*} \\
(0.096)\end{array}$ & $\begin{array}{l}-0.699 \\
(0.102)\end{array}$ & $\begin{array}{l}-0.672 \\
(0.116)\end{array}$ & $\begin{array}{l}-0.478 \\
(0.267)\end{array}$ & $\begin{array}{l}-0.684 \\
(0.110)\end{array}$ \\
\hline FIND & & & $\begin{array}{l}0.036^{* * * *} \\
(0.001)\end{array}$ & $\begin{array}{l}0.034^{* * *} \\
(0.002)\end{array}$ & $\begin{array}{l}0.025^{* *} \\
(0.027)\end{array}$ & $\begin{array}{l}0.029^{* * *} \\
(0.007)\end{array}$ & $\begin{array}{l}0.038^{* * * *} \\
(0.001)\end{array}$ \\
\hline SMD & & & $\begin{array}{l}0.003 \\
(0.404)\end{array}$ & & & & \\
\hline RL & & & & $\begin{array}{l}0.186 \\
(0.126)\end{array}$ & & & \\
\hline RE & & & & & $\begin{array}{l}0.256^{* *} \\
(0.017)\end{array}$ & & \\
\hline CORR & & & & & & $\begin{array}{l}-0.282^{* * * *} \\
(0.000)\end{array}$ & \\
\hline CR & & & & & & & $\begin{array}{l}0.532^{* *} \\
(0.021)\end{array}$ \\
\hline Intercept & $\begin{array}{l}-0.136^{* * * *} \\
(0.000)\end{array}$ & $\begin{array}{l}-0.137^{* * *} \\
(0.000)\end{array}$ & $\begin{array}{l}-0.105^{* * * *} \\
(0.000)\end{array}$ & $\begin{array}{l}-0.116^{* * *} \\
(0.000)\end{array}$ & $\begin{array}{l}-0.124^{* * *} \\
(0.000)\end{array}$ & $\begin{array}{l}-0.114^{* * *} \\
(0.000)\end{array}$ & $\begin{array}{l}-0.110^{* * * *} \\
(0.000)\end{array}$ \\
\hline Adjusted $\mathrm{R}^{2}$ & 0.510 & 0.520 & 0.521 & 0.524 & 0.523 & 0.535 & 0.533 \\
\hline Wald test & $\begin{array}{l}1415.72^{* * * *} \\
(0.000)\end{array}$ & $\begin{array}{l}1419.49^{\text {**** }} \\
(0.000)\end{array}$ & $\begin{array}{l}1445.14^{* * *} \\
(0.000)\end{array}$ & $\begin{array}{l}1454.49^{* * *} \\
(0.000)\end{array}$ & $\begin{array}{l}1456.75^{\text {**** }} \\
(0.000)\end{array}$ & $\begin{array}{l}1470.47^{* * *} \\
(0.000)\end{array}$ & $\begin{array}{l}1451.36^{* * *} \\
(0.000)\end{array}$ \\
\hline Industry effect & Yes & Yes & Yes & Yes & Yes & Yes & Yes \\
\hline Year effect & Yes & Yes & Yes & Yes & Yes & Yes & Yes \\
\hline Observations & 3717 & 3717 & 3717 & 3717 & 3717 & 3717 & 3717 \\
\hline Firms & 444 & 444 & 444 & 444 & 444 & 444 & 444 \\
\hline
\end{tabular}

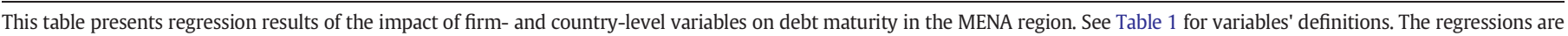

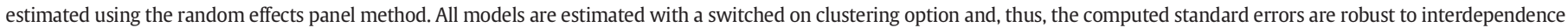
in cross-country error terms. Numbers in parentheses indicate p- values.

* Significance at $10 \%$ level.

** Significance at the $5 \%$ level.

*** Significance at the $1 \%$ level.

In column (7), besides firm-level factors, macroeconomic and financial intermediaries' development variables, we include CR as a measure of creditor rights' protection. Consistent with the view that lenders are more willing to extend long-term credit in environments of stronger creditor rights, we find a positive and significant association at the $5 \%$ level between CR and DMAT. The economic magnitude of the coefficient estimate on CR suggests a substantial impact of the extent to which creditors are protected against borrower expropriation on firms' access to long-term debt. Specifically, a 1-unit increase in the CR index increases the proportion of long-term debt in MENA firms' total debt by 53.2\%. This finding highlights the importance of reforming creditor and bankruptcy regimes to increase creditors' protection and thereby enhance their incentives to extend long-term debt to firms. Specifically, firms located in Oman and Tunisia, where CR equals zero, would gain access to much more long-term debt if creditor rights are strengthened. This finding together with the finding that financial development (FIND) is positively associated with DMAT suggests that banks play an important role in firms' access to long-term debt. In other words, in the presence of well-developed banks that are granted sufficient creditor rights, firms can raise more long-term debt. However, in environments of insufficient financial development and where creditor rights are weak, banks are reluctant to extend long-term credit to firms.
In sum, our results suggest that the quality of institutions is an important determinant of corporate debt maturity in the MENA region and that our documented limited use of long-term debt in the region is at least partly due to weak institutional environments that prevail in most countries. As financial development, public governance, and creditors' legal protection improve firms in the region tend to use more long-term debt. MENA countries challenged with high unemployment rates and low private investment rates would hence gain in terms of their firms' access to long-term debt - and thereby more long-term investment and employment - by implementing reforms that enhance public governance, strengthen the financial system, and improve creditors' legal protection.

\subsection{Robustness analyses}

\subsubsection{Alternative estimation methods}

In Table 8, we analyze whether our results reported in Table 7 continue to hold when we use alternative regression techniques. ${ }^{20}$ In models

\footnotetext{
${ }^{20}$ We also estimate models that include SMD, but do not report them for the sake of space since SMD appears insignificant in all these models no matter what estimation technique is used.
} 
Table 8

Alternative estimation methods.

\begin{tabular}{|c|c|c|c|c|c|c|c|c|c|c|c|c|}
\hline \multirow[b]{2}{*}{ Variable } & \multicolumn{4}{|l|}{ OLS } & \multicolumn{4}{|c|}{ Firm fixed effects } & \multicolumn{4}{|l|}{ 2SLS } \\
\hline & (1) & (2) & (3) & (4) & (5) & (6) & (7) & (8) & (9) & $(10)$ & (11) & (12) \\
\hline LEV & $\begin{array}{l}0.342^{* * *} \\
(0.000)\end{array}$ & $\begin{array}{l}0.339^{* * * *} \\
(0.000)\end{array}$ & $\begin{array}{l}0.344^{* * *} \\
(0.000)\end{array}$ & $\begin{array}{l}0.333^{* * *} \\
(0.000)\end{array}$ & $\begin{array}{l}0.471^{* * * *} \\
(0.000)\end{array}$ & $\begin{array}{l}0.470^{* * * *} \\
(0.000)\end{array}$ & $\begin{array}{l}0.469^{* * *} \\
(0.000)\end{array}$ & $\begin{array}{l}0.471^{* * *} \\
(0.000)\end{array}$ & $\begin{array}{l}0.379^{* * * *} \\
(0.000)\end{array}$ & $\begin{array}{l}0.378^{* * * *} \\
(0.000)\end{array}$ & $\begin{array}{l}0.379^{* * *} \\
(0.000)\end{array}$ & $\begin{array}{l}0.375^{* * * *} \\
(0.000)\end{array}$ \\
\hline SIZE & $\begin{array}{l}0.867^{* *} \\
(0.023)\end{array}$ & $\begin{array}{l}0.937^{* *} \\
(0.015)\end{array}$ & $\begin{array}{l}0.703^{*} \\
(0.063)\end{array}$ & $\begin{array}{l}1.182^{* * * *} \\
(0.007)\end{array}$ & $\begin{array}{l}0.657^{*} \\
(0.068)\end{array}$ & $\begin{array}{l}0.569 \\
(0.151)\end{array}$ & $\begin{array}{l}0.594^{*} \\
(0.093)\end{array}$ & $\begin{array}{l}0.586^{*} \\
(0.073)\end{array}$ & $\begin{array}{l}0.807^{*} \\
(0.097)\end{array}$ & $\begin{array}{l}0.764 \\
(0.115)\end{array}$ & $\begin{array}{l}0.705 \\
(0.143)\end{array}$ & $\begin{array}{l}0.877^{*} \\
(0.099)\end{array}$ \\
\hline GROWTH & $\begin{array}{l}-0.021^{* *} \\
(0.035)\end{array}$ & $\begin{array}{l}-0.021^{* * *} \\
(0.007)\end{array}$ & $\begin{array}{l}-0.021^{* *} \\
(0.032)\end{array}$ & $\begin{array}{l}-0.020^{* *} \\
(0.034)\end{array}$ & $\begin{array}{l}-0.035^{* *} \\
(0.024)\end{array}$ & $\begin{array}{l}-0.036^{* *} \\
(0.021)\end{array}$ & $\begin{array}{l}-0.034^{* *} \\
(0.027)\end{array}$ & $\begin{array}{l}-0.035^{* *} \\
(0.022)\end{array}$ & $\begin{array}{l}-0.025^{*} \\
(0.057)\end{array}$ & $\begin{array}{l}-0.025^{*} \\
(0.060)\end{array}$ & $\begin{array}{l}-0.025^{*} \\
(0.063)\end{array}$ & $\begin{array}{l}-0.025^{*} \\
(0.060)\end{array}$ \\
\hline PPE & $\begin{array}{l}0.115^{* * *} \\
(0.000)\end{array}$ & $\begin{array}{l}0.115^{* * *} \\
(0.000)\end{array}$ & $\begin{array}{l}0.118^{* * *} \\
(0.000)\end{array}$ & $\begin{array}{l}0.110^{* * * *} \\
(0.000)\end{array}$ & $\begin{array}{l}0.113^{* * *} \\
(0.000)\end{array}$ & $\begin{array}{l}0.114^{* * *} \\
(0.000)\end{array}$ & $\begin{array}{l}0.113^{* * *} \\
(0.000)\end{array}$ & $\begin{array}{l}0.114^{* * * *} \\
(0.000)\end{array}$ & $\begin{array}{l}0.117^{* * *} \\
(0.000)\end{array}$ & $\begin{array}{l}0.116^{* * * *} \\
(0.000)\end{array}$ & $\begin{array}{l}0.118^{* * *} \\
(0.000)\end{array}$ & $\begin{array}{l}0.115^{* * * *} \\
(0.000)\end{array}$ \\
\hline AMAT & $\begin{array}{l}0.000 \\
(0.684)\end{array}$ & $\begin{array}{l}0.000 \\
(0.510)\end{array}$ & $\begin{array}{l}0.000 \\
(0.620)\end{array}$ & $\begin{array}{l}0.000 \\
(0.653)\end{array}$ & $\begin{array}{l}0.000 \\
(0.966)\end{array}$ & $\begin{array}{l}0.000 \\
(0.923)\end{array}$ & $\begin{array}{l}0.000 \\
(0.856)\end{array}$ & $\begin{array}{l}0.000 \\
(0.926)\end{array}$ & $\begin{array}{l}0.000 \\
(0.811)\end{array}$ & $\begin{array}{l}0.000 \\
(0.799)\end{array}$ & $\begin{array}{l}0.000 \\
(0.714)\end{array}$ & $\begin{array}{l}0.000 \\
(0.778)\end{array}$ \\
\hline Z-SCORE & $\begin{array}{l}0.688^{* * *} \\
(0.000)\end{array}$ & $\begin{array}{l}0.638^{* * * *} \\
(0.000)\end{array}$ & $\begin{array}{l}0.634^{* * *} \\
(0.000)\end{array}$ & $\begin{array}{l}0.539^{* * *} \\
(0.000)\end{array}$ & $\begin{array}{l}0.445^{* * *} \\
(0.000)\end{array}$ & $\begin{array}{l}0.401^{* * *} \\
(0.000)\end{array}$ & $\begin{array}{l}0.327^{* * * *} \\
(0.000)\end{array}$ & $\begin{array}{l}0.376^{* * *} \\
(0.000)\end{array}$ & $\begin{array}{l}0.708 \\
(0.112)\end{array}$ & $\begin{array}{l}0.751^{*} \\
(0.091)\end{array}$ & $\begin{array}{l}0.718 \\
(0.105)\end{array}$ & $\begin{array}{l}0.795^{*} \\
(0.077)\end{array}$ \\
\hline ROA & $\begin{array}{l}-0.196^{* * *} \\
(0.000)\end{array}$ & $\begin{array}{l}-0.194^{* * *} \\
(0.000)\end{array}$ & $\begin{array}{l}-0.199^{* * *} \\
(0.000)\end{array}$ & $\begin{array}{l}-0.187^{* * *} \\
(0.001)\end{array}$ & $\begin{array}{l}0.170^{* * * *} \\
(0.000)\end{array}$ & $\begin{array}{l}0.161^{\text {**** }} \\
(0.000)\end{array}$ & $\begin{array}{l}0.158^{* * * *} \\
(0.000)\end{array}$ & $\begin{array}{l}0.159^{* * *} \\
(0.000)\end{array}$ & $\begin{array}{l}0.128^{* *} \\
(0.046)\end{array}$ & $\begin{array}{l}0.130^{* *} \\
(0.042)\end{array}$ & $\begin{array}{l}0.134^{* *} \\
(0.036)\end{array}$ & $\begin{array}{l}0.129^{* *} \\
(0.043)\end{array}$ \\
\hline ETR & $\begin{array}{l}0.856^{* *} \\
(0.021)\end{array}$ & $\begin{array}{l}0.863^{* * * *} \\
(0.008)\end{array}$ & $\begin{array}{l}0.846^{* *} \\
(0.021)\end{array}$ & $\begin{array}{l}0.879 \\
(0.229)\end{array}$ & $\begin{array}{l}0.741^{* * * *} \\
(0.000)\end{array}$ & $\begin{array}{l}0.739^{* * * *} \\
(0.000)\end{array}$ & $\begin{array}{l}0.733^{* * *} \\
(0.000)\end{array}$ & $\begin{array}{l}0.738^{* * *} \\
(0.000)\end{array}$ & $\begin{array}{l}0.764^{* * * *} \\
(0.000)\end{array}$ & $\begin{array}{l}0.766^{* * * *} \\
(0.000)\end{array}$ & $\begin{array}{l}0.756^{* * * *} \\
(0.000)\end{array}$ & $\begin{array}{l}0.768^{* * * *} \\
(0.000)\end{array}$ \\
\hline GDPG & $\begin{array}{l}0.247^{*} \\
(0.063)\end{array}$ & $\begin{array}{l}0.223 \\
(0.093)\end{array}$ & $\begin{array}{l}0.256^{*} \\
(0.058)\end{array}$ & $\begin{array}{l}0.288^{*} \\
(0.088)\end{array}$ & $\begin{array}{l}6.734 \\
(0.341)\end{array}$ & $\begin{array}{l}0.238 \\
(0.971)\end{array}$ & $\begin{array}{l}0.978 \\
(0.880)\end{array}$ & $\begin{array}{l}0.978 \\
(0.990)\end{array}$ & $\begin{array}{l}1.458 \\
(0.816)\end{array}$ & $\begin{array}{l}1.403 \\
(0.462)\end{array}$ & $\begin{array}{l}1.705 \\
(0.776)\end{array}$ & $\begin{array}{l}1.227 \\
(0.379)\end{array}$ \\
\hline INF & $\begin{array}{l}-0.777 \\
(0.395)\end{array}$ & $\begin{array}{c}-0.785 \\
(0.253)\end{array}$ & $\begin{array}{c}-0.505 \\
(0.754)\end{array}$ & $\begin{array}{l}-0.522 \\
(0.285)\end{array}$ & $\begin{array}{l}-0.920^{* *} \\
(0.024)\end{array}$ & $\begin{array}{l}-0.854^{* *} \\
(0.050)\end{array}$ & $\begin{array}{l}-0.733^{* *} \\
(0.032)\end{array}$ & $\begin{array}{l}-0.752^{* *} \\
(0.026)\end{array}$ & $\begin{array}{c}-0.942^{*} \\
(0.083)\end{array}$ & $\begin{array}{l}-0.744^{*} \\
(0.054)\end{array}$ & $\begin{array}{l}-0.602 \\
(0.175)\end{array}$ & $\begin{array}{l}-0.738^{* *} \\
(0.048)\end{array}$ \\
\hline FIND & $\begin{array}{l}0.017^{* * *} \\
(0.008)\end{array}$ & $\begin{array}{l}0.010^{* *} \\
(0.040)\end{array}$ & $\begin{array}{l}0.018^{* * *} \\
(0.006)\end{array}$ & $\begin{array}{l}0.026^{\text {**** }} \\
(0.000)\end{array}$ & $\begin{array}{l}0.053^{* * * *} \\
(0.001)\end{array}$ & $\begin{array}{l}0.055^{* * *} \\
(0.000)\end{array}$ & $\begin{array}{l}0.055^{* * *} \\
(0.000)\end{array}$ & $\begin{array}{l}0.059^{* * *} \\
(0.000)\end{array}$ & $\begin{array}{l}0.033^{* * * *} \\
(0.003)\end{array}$ & $\begin{array}{l}0.037^{\text {***** }} \\
(0.000)\end{array}$ & $\begin{array}{l}0.033^{\text {**** }} \\
(0.001)\end{array}$ & $\begin{array}{l}0.039^{* * * *} \\
(0.000)\end{array}$ \\
\hline RL & $\begin{array}{l}0.171^{* * *} \\
(0.000)\end{array}$ & & & & $\begin{array}{l}0.167^{* *} \\
(0.025)\end{array}$ & & & & $\begin{array}{l}0.304 \\
(0.283)\end{array}$ & & & \\
\hline $\mathrm{RE}$ & & $\begin{array}{l}0.430^{* * *} \\
(0.000)\end{array}$ & & & & $\begin{array}{l}0.787^{* *} \\
(0.023)\end{array}$ & & & & $\begin{array}{l}0.469^{* *} \\
(0.023)\end{array}$ & & \\
\hline CORR & & & $\begin{array}{l}-0.295^{* * *} \\
(0.000)\end{array}$ & & & & $\begin{array}{l}-0.846^{* *} \\
(0.021)\end{array}$ & & & & $\begin{array}{l}-0.795^{* * * *} \\
(0.000)\end{array}$ & \\
\hline CR & & & & $\begin{array}{l}0.762^{* * * *} \\
(0.002)\end{array}$ & & & & $\begin{array}{l}0.501^{* *} \\
(0.031)\end{array}$ & & & & $\begin{array}{l}0.339^{* *} \\
(0.043)\end{array}$ \\
\hline Intercept & $\begin{array}{l}-0.758^{* * *} \\
(0.000)\end{array}$ & $\begin{array}{l}-0.633^{* * *} \\
(0.000)\end{array}$ & $\begin{array}{l}-0.506^{* * *} \\
(0.000)\end{array}$ & $\begin{array}{l}-0.586^{* * * *} \\
(0.000)\end{array}$ & $\begin{array}{l}-0.831^{*} \\
(0.061)\end{array}$ & $\begin{array}{l}-0.512^{* *} \\
(0.036)\end{array}$ & $\begin{array}{l}-0.529^{* *} \\
(0.017)\end{array}$ & $\begin{array}{l}-0.550^{* *} \\
(0.021)\end{array}$ & $\begin{array}{l}-0.405^{* * *} \\
(0.000)\end{array}$ & $\begin{array}{l}-0.434^{\text {**** }} \\
(0.000)\end{array}$ & $\begin{array}{l}-0.543^{* * *} \\
(0.000)\end{array}$ & $\begin{array}{l}-0.462^{* * *} \\
(0.000)\end{array}$ \\
\hline Adjusted $\mathrm{R}^{2}$ & 0.532 & 0.531 & 0.532 & 0.463 & 0.432 & 0.441 & 0.435 & 0.436 & 0.514 & 0.514 & 0.517 & 0.516 \\
\hline Industry effect & Yes & Yes & Yes & Yes & No & No & No & No & Yes & Yes & Yes & Yes \\
\hline Year effect & Yes & Yes & Yes & Yes & Yes & Yes & Yes & Yes & Yes & Yes & Yes & Yes \\
\hline Observations & 3717 & 3717 & 3717 & 3717 & 3717 & 3717 & 3717 & 3717 & 3717 & 3717 & 3717 & 426 \\
\hline Firms & 444 & 444 & 444 & 444 & 444 & 444 & 444 & 444 & 444 & 444 & 444 & 117 \\
\hline
\end{tabular}

IV-GMM

\begin{tabular}{|c|c|c|c|c|c|c|c|c|}
\hline \multirow[b]{2}{*}{ Variable } & \multicolumn{4}{|l|}{ IV-GMM } & \multicolumn{4}{|c|}{ Random effects Tobit model } \\
\hline & (13) & (14) & $(15)$ & $(16)$ & $(17)$ & (18) & (19) & (20) \\
\hline LEV & $\begin{array}{l}0.307^{* * *} \\
(0.000)\end{array}$ & $\begin{array}{l}0.307^{* * *} \\
(0.000)\end{array}$ & $\begin{array}{l}0.305^{* * *} \\
(0.000)\end{array}$ & $\begin{array}{l}0.304^{* * *} \\
(0.000)\end{array}$ & $\begin{array}{l}0.480^{* * * *} \\
(0.000)\end{array}$ & $\begin{array}{l}0.480^{* * * *} \\
(0.000)\end{array}$ & $\begin{array}{l}0.476^{\text {*** }} \\
(0.000)\end{array}$ & $\begin{array}{l}0.482^{\text {*** }} \\
(0.000)\end{array}$ \\
\hline SIZE & $\begin{array}{l}0.746^{* * * *} \\
(0.003)\end{array}$ & $\begin{array}{l}0.739^{* * * *} \\
(0.003)\end{array}$ & $\begin{array}{l}0.660^{* * * *} \\
(0.007)\end{array}$ & $\begin{array}{l}0.678^{* * * *} \\
(0.002)\end{array}$ & $\begin{array}{l}0.993^{* * * *} \\
(0.000)\end{array}$ & $\begin{array}{l}0.955^{* * * *} \\
(0.000)\end{array}$ & $\begin{array}{l}0.852^{* * * *} \\
(0.000)\end{array}$ & $\begin{array}{l}0.832^{* * * *} \\
(0.000)\end{array}$ \\
\hline GROWTH & $\begin{array}{l}-0.010^{*} \\
(0.059)\end{array}$ & $\begin{array}{c}-0.008 \\
(0.648)\end{array}$ & $\begin{array}{c}-0.011 \\
(0.532)\end{array}$ & $\begin{array}{l}-0.007 \\
(0.695)\end{array}$ & $\begin{array}{l}-0.020 \\
(0.230)\end{array}$ & $\begin{array}{l}-0.020 \\
(0.225)\end{array}$ & $\begin{array}{c}-0.020 \\
(0.224)\end{array}$ & $\begin{array}{c}-0.019 \\
(0.238)\end{array}$ \\
\hline PPE & $\begin{array}{l}0.074^{* * *} \\
(0.001)\end{array}$ & $\begin{array}{l}0.070^{* * *} \\
(0.001)\end{array}$ & $\begin{array}{l}0.071^{* * *} \\
(0.001)\end{array}$ & $\begin{array}{l}0.068^{* * *} \\
(0.002)\end{array}$ & $\begin{array}{l}0.206^{* * *} \\
(0.000)\end{array}$ & $\begin{array}{l}0.204^{* * *} \\
(0.000)\end{array}$ & $\begin{array}{l}0.204^{* * *} \\
(0.000)\end{array}$ & $\begin{array}{l}0.207^{* * *} \\
(0.000)\end{array}$ \\
\hline AMAT & $\begin{array}{l}0.000 \\
(0.416)\end{array}$ & $\begin{array}{l}0.000 \\
(0.667)\end{array}$ & $\begin{array}{l}0.000 \\
(0.617)\end{array}$ & $\begin{array}{l}0.000 \\
(0.607)\end{array}$ & $\begin{array}{l}0.000 \\
(0.586)\end{array}$ & $\begin{array}{l}0.000 \\
(0.561)\end{array}$ & $\begin{array}{l}0.000 \\
(0.562)\end{array}$ & $\begin{array}{l}0.000 \\
(0.489)\end{array}$ \\
\hline Z-SCORE & $\begin{array}{l}0.555^{* * * *} \\
(0.000)\end{array}$ & $\begin{array}{l}0.616^{* * * *} \\
(0.000)\end{array}$ & $\begin{array}{l}0.593^{* * * *} \\
(0.000)\end{array}$ & $\begin{array}{l}0.554^{* * * *} \\
(0.000)\end{array}$ & $\begin{array}{l}0.236^{*} \\
(0.073)\end{array}$ & $\begin{array}{l}0.290^{*} \\
(0.067)\end{array}$ & $\begin{array}{l}0.256^{*} \\
(0.082)\end{array}$ & $\begin{array}{l}0.231^{*} \\
(0.064)\end{array}$ \\
\hline ROA & $\begin{array}{l}-0.168^{* * *} \\
(0.000)\end{array}$ & $\begin{array}{l}-0.174^{* * *} \\
(0.000)\end{array}$ & $\begin{array}{l}-0.173^{* * *} \\
(0.000)\end{array}$ & $\begin{array}{l}-0.160^{* * *} \\
(0.000)\end{array}$ & $\begin{array}{l}-0.025^{*} \\
(0.063)\end{array}$ & $\begin{array}{l}-0.029^{*} \\
(0.058)\end{array}$ & $\begin{array}{l}-0.026^{*} \\
(0.062)\end{array}$ & $\begin{array}{l}-0.025^{*} \\
(0.063)\end{array}$ \\
\hline ETR & $\begin{array}{l}0.331^{* * *} \\
(0.000)\end{array}$ & $\begin{array}{l}0.332^{* * * *} \\
(0.000)\end{array}$ & $\begin{array}{l}0.327^{* * * *} \\
(0.000)\end{array}$ & $\begin{array}{l}0.321^{* * *} \\
(0.000)\end{array}$ & $\begin{array}{l}0.792^{* * *} \\
(0.000)\end{array}$ & $\begin{array}{l}0.793^{* * *} \\
(0.000)\end{array}$ & $\begin{array}{l}0.794^{* * *} \\
(0.000)\end{array}$ & $\begin{array}{l}0.780^{\text {***** }} \\
(0.000)\end{array}$ \\
\hline GDPG & $\begin{array}{l}0.188^{*} \\
(0.052)\end{array}$ & $\begin{array}{l}0.170^{*} \\
(0.061)\end{array}$ & $\begin{array}{l}0.181^{*} \\
(0.084)\end{array}$ & $\begin{array}{l}0.185^{*} \\
(0.073)\end{array}$ & $\begin{array}{l}0.404 \\
(0.315)\end{array}$ & $\begin{array}{l}0.034 \\
(0.474)\end{array}$ & $\begin{array}{l}0.036 \\
(0.260)\end{array}$ & $\begin{array}{l}0.046 \\
(0.594)\end{array}$ \\
\hline INF & $\begin{array}{l}-0.406 \\
(0.911)\end{array}$ & $\begin{array}{l}-0.785 \\
(0.831)\end{array}$ & $\begin{array}{l}-0.547 \\
(0.883)\end{array}$ & $\begin{array}{l}-0.483 \\
(0.704)\end{array}$ & $\begin{array}{l}-0.455 \\
(0.900)\end{array}$ & $\begin{array}{l}-0.424 \\
(0.734)\end{array}$ & $\begin{array}{l}-0.526 \\
(0.880)\end{array}$ & $\begin{array}{l}-0.594 \\
(0.826)\end{array}$ \\
\hline FIND & $\begin{array}{l}0.015^{* * *} \\
(0.009)\end{array}$ & $\begin{array}{l}0.013^{* * * *} \\
(0.008)\end{array}$ & $\begin{array}{l}0.011^{* * *} \\
(0.000)\end{array}$ & $\begin{array}{l}0.010^{* * *} \\
(0.008)\end{array}$ & $\begin{array}{l}0.092^{* * *} \\
(0.007)\end{array}$ & $\begin{array}{l}0.079^{* * *} \\
(0.008)\end{array}$ & $\begin{array}{l}0.086^{* * *} \\
(0.008)\end{array}$ & $\begin{array}{l}0.084^{* * *} \\
(0.081)\end{array}$ \\
\hline RL & $\begin{array}{l}0.153^{* *} \\
(0.021)\end{array}$ & & & & $\begin{array}{l}0.129^{* *} \\
(0.022)\end{array}$ & & & \\
\hline RE & & $\begin{array}{l}0.394^{* * *} \\
(0.007)\end{array}$ & & & & $\begin{array}{l}0.447^{* *} \\
(0.019)\end{array}$ & & \\
\hline CORR & & & $\begin{array}{l}-0.807^{* * *} \\
(0.000)\end{array}$ & & & & $\begin{array}{l}-0.721^{* *} \\
(0.028)\end{array}$ & \\
\hline CR & & & & $\begin{array}{l}0.583^{* * *} \\
(0.000)\end{array}$ & & & & $\begin{array}{l}0.968^{* * *} \\
(0.000)\end{array}$ \\
\hline Intercept & $\begin{array}{l}-0.800^{* * *} \\
(0.004)\end{array}$ & $\begin{array}{l}-0.543^{* * *} \\
(0.000)\end{array}$ & $\begin{array}{l}-0.549^{* * * *} \\
(0.000)\end{array}$ & $\begin{array}{l}-0.628^{* * *} \\
(0.000)\end{array}$ & $\begin{array}{l}-2.895^{* * * *} \\
(0.000)\end{array}$ & $\begin{array}{l}-2.558^{* * * *} \\
(0.000)\end{array}$ & $\begin{array}{l}-2.429^{* * *} \\
(0.000)\end{array}$ & $\begin{array}{l}-2.438^{\text {**** }} \\
(0.000)\end{array}$ \\
\hline Adjusted R2 & 0.583 & 0.587 & 0.597 & 0.563 & - & - & - & - \\
\hline
\end{tabular}


Table 8 (continued)

\begin{tabular}{|c|c|c|c|c|c|c|c|c|}
\hline \multirow[b]{2}{*}{ Variable } & \multicolumn{4}{|l|}{ IV-GMM } & \multicolumn{4}{|c|}{ Random effects Tobit model } \\
\hline & $(13)$ & $(14)$ & (15) & $(16)$ & $(17)$ & $(18)$ & (19) & $(20)$ \\
\hline AR (1) & $\begin{array}{l}-1.272^{* *} \\
(0.011)\end{array}$ & $\begin{array}{l}-1.271^{* *} \\
(0.010)\end{array}$ & $\begin{array}{l}-1.258^{* *} \\
(0.011)\end{array}$ & $\begin{array}{l}-1.260^{* *} \\
(0.011)\end{array}$ & - & - & - & - \\
\hline AR (2) & $\begin{array}{l}0.381 \\
(0.702)\end{array}$ & $\begin{array}{l}0.364 \\
(0.715)\end{array}$ & $\begin{array}{l}0.363 \\
(0.715)\end{array}$ & $\begin{array}{l}0.380 \\
(0.703)\end{array}$ & - & - & - & - \\
\hline Sargan test & $\begin{array}{l}59.668 \\
(0.246)\end{array}$ & $\begin{array}{l}59.002 \\
(0.265)\end{array}$ & $\begin{array}{l}59.270 \\
(0.227)\end{array}$ & $\begin{array}{l}63.015 \\
(0.163)\end{array}$ & - & - & - & - \\
\hline Industry effect & Yes & Yes & Yes & Yes & Yes & Yes & Yes & Yes \\
\hline Year effect & Yes & Yes & Yes & Yes & Yes & Yes & Yes & Yes \\
\hline Observations & 3717 & 3717 & 3717 & 3717 & 3717 & 3717 & 3717 & 3717 \\
\hline Firms & 444 & 444 & 444 & 444 & 444 & 444 & 444 & 444 \\
\hline
\end{tabular}

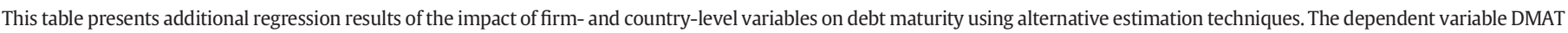

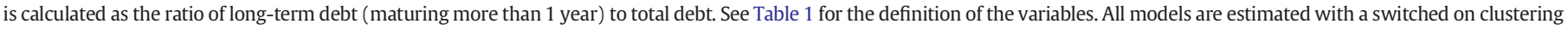

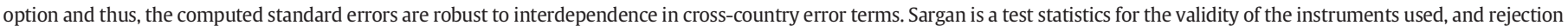
implies that the instruments are not valid. AR(1) and AR(2) are tests statistics for first and second order autocorrelations, respectively. Numbers in parentheses indicate p- values.

* Significance at $10 \%$ level.

** Significance at the $5 \%$ level.

*** Significance at the $1 \%$ level.

(1)-(4), we re-run our regressions using the ordinary least squares technique, as in Barclay and Smith (1995) and Guedes and Oplar (1996). All specifications include industry dummies and time dummies, which control for time-invariant industry-specific characteristics, and for a common time effects across firms. Consistent with what is reported in Table 7, we continue to find that LEV, SIZE, PPE, and Z-SCORE are positively and significantly associated with DMAT. Additionally, we report negative and significant relations between GROWTH and ROA and our dependent variable, DMAT. The result on GROWTH is consistent with Myers' underinvestment theory whereas the result on ROA - a proxy for firm quality - is in line with Flannery's signaling theory of debt maturity. As in Table 7, we report a positive and significant association between FIND, RE, CR, and DMAT. RL, which appeared positive but insignificant in Table 7, loads positive and significant in column (1). CORR continues to be inversely related to DMAT. Overall, the use of ordinary least squares reinforces our previous findings.

In columns (5)-(8), we present results based on the fixed effects method. This estimation technique of controls for unobserved firm heterogeneity (individual differences). In all the regressions, we include year dummies to account for different time periods that might effect on the fraction of long-term debt in a firm's debt capital. As the fixed effects are already controlling for all unobserved firm variables, including industry, we drop industry dummies from the regression equation to avoid collinearity. Our findings support our earlier statement that improving the institutional environment in the MENA countries would enhance firms' access to long-term debt. Firm-level variables also continue to be associated with DMAT as reported in Table 7 . We also notice that among the macroeconomic factors, INF, which appears insignificant across all models reported in Table 7 , loads consistently negative and significant at least at the $5 \%$ level in Table 8 . This result is consistent with argument that higher inflation rates reduce creditors' willingness to extend long-term credit due to concerns of increased loss of value of loaned capital in inflationary environments (e.g., Demirgüç-Kunt \& Maksimovic, 1999). We conclude that our results are robust to the use of firm fixed effects rather than random effects.

Following Johnson (2003), in models (9)-(12), we account for the potential simultaneous determination of debt maturity and financial leverage and estimate a simultaneous system of equations using the two-stage least squares technique (2SLS). In the leverage regression equation, we use the same explanatory variables as in the DMAT model, except that we add a lagged leverage variable to identify the leverage model. The unreported results of the leverage regression indicate that firm leverage is generally significantly associated with the explanatory variables, in line with prior research on the determinants of financial leverage. As regards the DMAT equation which is the subject of our focus, we find that the use of the 2SLS technique generates results that are generally consistent with those reported in Table 7 and with our expectations. In particular, our institutional variables continue to affect debt maturity in virtually the same way as what is reported in Table 7. We interpret this as evidence that our earlier results are not driven by the potential endogeneity of leverage.

To further verify that our earlier results are not driven by endogeneity, we also estimate our DMAT models using the Generalized Method of Moments estimator (IV-GMM). This estimator treats the explanatory variables as endogenous, with the exception of dummies. It is also more efficient than 2SLS because it accounts for heteroskedasticity (Hall, 2005) and does not require distributional assumptions on the error terms. As columns (13)-(16) of Table 8 show, the coefficient estimates of our explanatory variables in all specifications are generally consistent with those reported in Table 7 and very similar to what we obtain using the 2SLS technique. The IV-GMM estimations, therefore, reinforce our conclusions and confirm that our earlier results are not driven by endogeneity.

Because our dependent variable DMAT is truncated between 0 and 1 , we further check the robustness of our results using a random effects Tobit regression model. Our findings, reported in columns (17)-(20) of Table 8 are consistent with our main results reported in Table 7; we find that all our institutional variables continue to affect debt maturity in the same way reported earlier. Our results are thus robust to the use of various estimation methods. ${ }^{21}$

\subsubsection{Alternative measure of debt maturity}

In Table 9, we analyze whether our evidence of the firm- and country-level determinants of debt maturity in the MENA region is sensitive to the measure of debt maturity. After El Ghoul et al. (2014), we calculate DMAT2 as the ratio of total liabilities minus current liabilities to total liabilities and use it as our dependent variable in the debt maturity model. Models (1)-(5) of Table 9 replicate, respectively, models (3)-(7) of Table 7 using DMAT2 as the dependent variable instead of DMAT. As regards firm-level factors, our five models reinforce our findings reported in both Tables 6 and 7 that firms' use of long-term debt increases with leverage, size, tangible assets, lower default risk, and greater tax rates. Consistent with results reported in Table 7, apart

\footnotetext{
${ }^{21}$ For the sake of robustness check we also run the same model specifications as in Table 7 using a random effects logit regression model. In this model, we code the dependent variable as one if the firm has a high level of long term debt (higher than the 3rd quartile) and zero for firms with low levels of long term debt (1st quartile and below) in a given year. This alternative method generates results (not reported for the sake of space, but available upon request) similar to those reported in Table 7. Therefore, our results do not seem to be affected by extreme values of long term debt.
} 
Table 9

Alternative debt maturity measure.

\begin{tabular}{|c|c|c|c|c|}
\hline \multirow[b]{2}{*}{ Variable } & \multicolumn{4}{|c|}{ Long-term liabilities to total liabilities (DMAT2) } \\
\hline & (1) & $(2)$ & (3) & (4) \\
\hline LEV & $\begin{array}{l}0.209^{* * *} \\
(0.000)\end{array}$ & $\begin{array}{l}0.210^{* * *} \\
(0.000)\end{array}$ & $\begin{array}{l}0.210^{* * * *} \\
(0.000)\end{array}$ & $\begin{array}{l}0.197^{* * *} \\
(0.000)\end{array}$ \\
\hline SIZE & $\begin{array}{l}0.917^{\text {**** }} \\
(0.000)\end{array}$ & $\begin{array}{l}0.921^{* * *} \\
(0.000)\end{array}$ & $\begin{array}{l}0.913^{\text {*** }} \\
(0.000)\end{array}$ & $\begin{array}{l}0.981^{* * * *} \\
(0.000)\end{array}$ \\
\hline GROWTH & $\begin{array}{l}0.019 \\
(0.408)\end{array}$ & $\begin{array}{l}0.018 \\
(0.438)\end{array}$ & $\begin{array}{l}0.020 \\
(0.393)\end{array}$ & $\begin{array}{l}0.019 \\
(0.406)\end{array}$ \\
\hline PPE & $\begin{array}{l}0.281^{* * *} \\
(0.000)\end{array}$ & $\begin{array}{l}0.280^{* * *} \\
(0.000)\end{array}$ & $\begin{array}{l}0.284^{* * *} \\
(0.000)\end{array}$ & $\begin{array}{l}0.278^{* * *} \\
(0.000)\end{array}$ \\
\hline AMAT & $\begin{array}{l}0.000 \\
(0.972)\end{array}$ & $\begin{array}{l}0.000 \\
(0.985)\end{array}$ & $\begin{array}{l}0.000 \\
(0.897)\end{array}$ & $\begin{array}{l}0.000 \\
(0.915)\end{array}$ \\
\hline Z-SCORE & $\begin{array}{l}0.853^{* * *} \\
(0.026)\end{array}$ & $\begin{array}{l}0.899^{* *} \\
(0.023)\end{array}$ & $\begin{array}{l}0.909^{* *} \\
(0.023)\end{array}$ & $\begin{array}{l}0.571^{* *} \\
(0.045)\end{array}$ \\
\hline ROA & $\begin{array}{l}-0.072 \\
(0.209)\end{array}$ & $\begin{array}{l}-0.073 \\
(0.202)\end{array}$ & $\begin{array}{l}-0.071 \\
(0.216)\end{array}$ & $\begin{array}{c}-0.068 \\
(0.231)\end{array}$ \\
\hline ETR & $\begin{array}{l}0.212^{*} \\
(0.079)\end{array}$ & $\begin{array}{l}0.205^{*} \\
(0.088)\end{array}$ & $\begin{array}{l}0.206^{*} \\
(0.087)\end{array}$ & $\begin{array}{l}0.211^{* *} \\
(0.080)\end{array}$ \\
\hline GDPG & $\begin{array}{l}0.065 \\
(0.829)\end{array}$ & $\begin{array}{l}0.672 \\
(0.086)\end{array}$ & $\begin{array}{l}0.051 \\
(0.946)\end{array}$ & $\begin{array}{l}0.087 \\
(0.662)\end{array}$ \\
\hline INF & $\begin{array}{l}-0.491^{* * *} \\
(0.006)\end{array}$ & $\begin{array}{l}-0.421^{* * *} \\
(0.006)\end{array}$ & $\begin{array}{l}-0.455^{* *} \\
(0.031)\end{array}$ & $\begin{array}{l}-0.427^{* * * *} \\
(0.009)\end{array}$ \\
\hline FIND & $\begin{array}{l}0.075^{* * *} \\
(0.000)\end{array}$ & $\begin{array}{l}0.044^{* *} \\
(0.037)\end{array}$ & $\begin{array}{l}0.065^{* * *} \\
(0.001)\end{array}$ & $\begin{array}{l}0.081^{* * * *} \\
(0.000)\end{array}$ \\
\hline RL & $\begin{array}{l}0.692^{* * * *} \\
(0.009)\end{array}$ & & & \\
\hline RE & & $\begin{array}{l}0.903^{\text {*** }} \\
(0.000)\end{array}$ & & \\
\hline CORR & & & $\begin{array}{l}-0.899^{* * *} \\
(0.000)\end{array}$ & \\
\hline CR & & & & $\begin{array}{l}0.196^{* * * *} \\
(0.000)\end{array}$ \\
\hline Intercept & $\begin{array}{l}-0.332^{\text {**** }} \\
(0.000)\end{array}$ & $\begin{array}{l}-0.352^{* * *} \\
(0.000)\end{array}$ & $\begin{array}{l}-0.368^{\text {*** }} \\
(0.000)\end{array}$ & $\begin{array}{l}-0.329^{* * *} \\
(0.000)\end{array}$ \\
\hline Adjusted $\mathrm{R}^{2}$ & 0.460 & 0.464 & 0.463 & 0.463 \\
\hline Wald test & $\begin{array}{l}474.75^{* * *} \\
(0.000)\end{array}$ & $\begin{array}{l}489.51^{* * *} \\
(0.000)\end{array}$ & $\begin{array}{l}486.57^{* * *} \\
(0.000)\end{array}$ & $\begin{array}{l}481.56^{* * *} \\
(0.000)\end{array}$ \\
\hline Industry effect & Yes & Yes & Yes & Yes \\
\hline Year effect & Yes & Yes & Yes & Yes \\
\hline Observations & 3717 & 3717 & 3717 & 3717 \\
\hline Firms & 444 & 444 & 444 & 444 \\
\hline
\end{tabular}

This table presents regression results of the impact of firm- and country-level variables on debt maturity measured by Long-term liabilities to total liabilities (DMAT2). See Table 1 for the definition of the variables. The regressions are estimated using the random effects panel method. All models are estimated with a switched on clustering option and thus, the computed standard errors are robust to interdependence in cross-country error terms. Numbers in parentheses indicate p- values.

* Significance at $10 \%$ level.

** Significance at the $5 \%$ level.

*** Significance at the $1 \%$ level.

from SMD, our institutional variables are significantly associated with debt maturity; greater financial intermediation development, stronger rule of law, better regulatory effectiveness, and stronger protection of creditors, and more corruption enhance firms' access to long-term debt. In sum, our results reported earlier in the main analysis (Table 7) are robust to the use of another measure of debt maturity (DMAT2).

\section{Conclusions}

According to the most recent World Bank Enterprise Surveys database, $40 \%$ of MENA firms identify access to finance as a major constraint in doing business. In parallel with this, recent research shows that access to finance depends, among others, on the institutional environment in which the firm is operating (e.g., Booth, Aivazian, Demirguc-Kunt, \& Maksomovic, 2001; Giannetti, 2003; Antoniou et al., 2008; De Jong, Kabir, \& Nguyen, 2008; Gungoraydinoglu \& Oztekin, 2011; Fan et al., 2012; Oztekin \& Flannery, 2012). Specifically, prior research suggests that better institutional environments facilitate firms' access to debt capital in general, and long-term debt in particular. Yet, this research does not cover the MENA region. Consequently, very little, if any, is known on the financial structures of firms located in this region and on whether they are determined by the same firm and institutional factors as those of firms located in other parts of the world.

In this paper, we fill part of this gap in the literature by investigating the state of corporate debt maturity and its firm and institutional determinants in the MENA. Using a sample of 444 listed firms over the 20032011 period, or 3717 firm-year observations, we find a very limited use of long-term debt by MENA firms; long-term debt represents only $2.45 \%$ of the typical MENA firm's total debt, which is much less than what is reported in prior literature on other parts of the world. In step with extant literature, we further find that leverage, firm size, asset tangibility are all positively associated with debt maturity. Default risk is inversely related to debt maturity, consistent with the findings of prior literature on other parts of the world. In addition, we find that better quality institutions lead to the use of more long-term debt by firms. Specifically, stronger rule of law, better regulatory effectiveness, better legal protection of creditor, and more developed financial intermediaries are associated with greater use of long-term borrowing by MENA firms.

Our analysis has several policy implications for the MENA countries. First, MENA countries should put the goal of enhancing their firms' access to external finance, especially long-term debt on top of their agendas. This is much needed as the alleviation of the problem of rampant unemployment faced by most MENA countries requires an increase in private investment, which is, in turn, conditional on firms' access to long-term capital. Second, MENA countries known to be lagging behind in terms of the quality of their public governance would gain substantially in terms' of their firms' access to long-term capital by introducing reforms that strengthen the rule of law and enhance regulatory quality. Third, reforming insolvency regimes and strengthening creditor rights would boost lenders' willingness to extend long-term credit. Finally, since the quasi totality of corporate loans in the MENA is raised from the banking system, MENA countries are encouraged to fasten the pace of bank reforms that would enhance the availability of credit, especially long-term credit.

\section{References}

Affinito, M., \& Tagliaferri, E. (2010). Why do (or did?) banks securitize their loans? Evidence from Italy. Bank of Italy temi di discussione (working paper) no. 741

Albuquerque, R., Bauer, G. H., \& Schneider, M. (2009). Global private information in international equity markets. Journal of Financial Economics, 94(1), 18-46.

Alvarez de la Campa, A. (2011). Increasing access to credit through reforming secured transactions in the MENA region. World bank policy research working paper series, Vol.

Antoniou, A., Guney, Y., \& Paudyal, K. (2006). The determinants of debt maturity structure: Evidence from France, Germany and the UK. European Financial Management, 12(2), 161-194.

Antoniou, A., Guney, Y., \& Paudyal, K. (2008). The determinants of capital structure: Capital market-oriented versus bank-oriented institutions. Journal of Financial and Quantitative Analysis, 43(01), 59-92.

Anzoategui, D., Martinez Peria, M. S., \& Rocha, R. R. (2010). Bank competition in the middle east and northern Africa region. Review of Middle East Economics and Finance, 6(2), 26-48.

Araujo, A. P., Ferreira, R. V., \& Funchal, B. (2012). The Brazilian bankruptcy law experience. Journal of Corporate Finance, 18(4), 994-1004.

Bae, K. H., \& Goyal, V. K. (2009). Creditor rights, enforcement, and bank loans. The Journal of Finance, 64(2), 823-860.

Barclay, M., \& Smith, C., Jr. (1995). The maturity structure of corporate debt. The Journal of Finance, 50, 609-632.

Barclay, M. J., Marx, L. M., \& Smith, C. W. (2003). The joint determination of leverage and maturity. Journal of Corporate Finance, 9(2), 149-167.

Barnea, A., Haugen, R. A., \& Senbet, L. W. (1980). A rational for debt maturity structure and call provisions in the agency theoretic framework. The Journal of Finance, 35, $1223-1234$.

Belkhir, M., Ben-Nasr, H., \& Boubaker, S. (2014). Labor protection and corporate debt maturity: International evidence. UAE university working paper.

Bell, A., \& Jones, K. (2015). Explaining fixed effects: Random effects modeling of timeseries cross-sectional and panel data. Political Science Research and Method, 3, $133-153$.

Berglöf, E., \& Von Thadden, E. L. (1994). Short-term versus long-term interests: Capita structure with multiple investors. The Quarterly Journal of Economics, 1055-1084.

Bevan, A., Estrin, S., \& Meyer, K. E. (2004). Foreign investment location and institutional development in transition economies. International Business Review, 13, 43-64. 
Booth, L., Aivazian, V., Demirguc-Kunt, A., \& Maksomovic, V. (2001). Capital structure in developing countries. Journal of Finance, 56, 87-130.

Brick, I. E., \& Ravid, A. (1985). On the relevance of debt maturity structure. The Journal of Finance, 40, 1423-1437.

Brockman, P., Martin, X., \& Unlu, E. (2010). Executive compensation and the maturity structure of corporate debt. The Journal of Finance, 65, 1123-1161.

Cai, K., Fairchild, R., \& Guney, Y. (2008). Debt maturity structure of Chinese companies. Pacific-Basin Finance Journal, 16(3), 268-297.

Campbell, J. Y. (1996). Understanding risk and return. The Journal of Political Economy, 104(2), 298-345.

Chang, C. (1989). Debt maturity structure and bankruptcy. Working paper. University of Minnesota.

Cho, S. S., El Ghoul, S., Guedhami, O., \& Suh, J. (2014). Creditor rights and capital structure: Evidence from international data. Journal of Corporate Finance, 25, 40-60.

Custódio, C., Ferreira, M. A., \& Laureano, L. (2013). Why are US firms using more shortterm debt? Journal of Financial Economics, 108(1), 182-212.

Datta, S., Iskandar-Datta, M., \& Patel, A. (2000). Some evidence on the uniqueness of initial public debt offerings. The Journal of Finance, 55(2), 715-743.

Datta, S., Iskandar-Datta, M., \& Raman, K. (2005). Managerial stock ownership and the maturity structure of corporate debt. The Journal of Finance, 60, 2333-2350.

De Jong, A., Kabir, R., \& Nguyen, T. T. (2008). Capital structure around the world: The roles of firm and country specific determinants. Journal of Banking E Finance, 32 1954-1969.

Demirgüç-Kunt, A., \& Maksimovic, V. (1998). Law, finance, and firm growth. The Journal of Finance, 53(6), 2107-2137.

Demirgüç-Kunt, A., \& Maksimovic, V. (1999). Institutions, financial markets, and firm debt maturity. Journal of Financial Economics, 54, 295-336.

Diamond, D. W. (1984). Financial intermediation and delegated monitoring. The Review of Economic Studies, 51(3), 393-414.

Diamond, D. W. (2004). Presidential address, committing to commit: Short-term debt when enforcement is costly. The Journal of Finance, 59(4), 1447-1479.

Diamond, D. W. (1991). Debt maturity and liquidity risk. Quarterly Journal of Economics, 106, 709-737.

Djankov, S., McLiesh, C., \& Shleifer, A. (2007). Private credit in 129 countries. Journal of Financial Economics, 84(2), 299-329.

El Ghoul, S., Guedhami, O., Pittman, J., \& Rizeanu, S. (2014). Cross-country evidence on the importance of auditor choice to corporate debt maturity. Contemporary Accounting Research (in press).

Fan, J. P., Titman, S., \& Twite, G. (2012). An international comparison of capital structure and debt maturity choices. Journal of Financial and Quantitative Analysis, 47(1), 23.

Flannery, M. J. (1986). Asymmetric information and risky debt maturity choice. The Journal of Finance, 41, 19-37.

García-Teruel, P. J., \& Martínez-Solano, P. (2010). Ownership structure and debt maturity: New evidence from Spain. Review of Quantitative Finance and Accounting, 35(4), 473-491.

Giannetti, M. (2003). Do better institutions mitigate agency problems? Evidence from corporate finance choices. Journal of Financial and Quantitative Analysis, 38(01), 185-212.

Grossman, S. (1976). On the efficiency of competitive stock markets where trades have diverse information. The Journal of Finance, 31(2), 573-585.

Guedes, J., \& Oplar, T. (1996). The determinants of the maturity of corporate debt issues. The Journal of Finance, 51, 1809-1834.

Gungoraydinoglu, A., \& Oztekin, O. (2011). Firm and country level determinants of corporate leverage: Some new international evidence. Journal of Corporate Finance, 17(5), $1457-1474$.

Hall, A. R. (2005). Generalized method of moments. Oxford: Oxford University Press.

Harford, J., Li, K., \& Zhao, X. (2008). Corporate boards and the leverage and debt maturity choices. International Journal of Corporate Governance, 1, 3-27.

Hart, O., \& Moore, J. (1994). Debt and seniority: An analysis of the role of hard claims in constraining management (no. w4886). National Bureau of Economic Research.
Haselmann, R., \& Wachtel, P. (2010). Institutions and bank behavior: legal environment, legal perception, and the composition of bank lending. Journal of Money, Credit and Banking, 42(5), 965-984.

Jiraporn, P. P., \& Kitsabunnarat, P. P. (2007). Debt maturity structure, shareholder rights and corporate governance (available at SSRN: http://ssrn.com/abstract=999265 or) http:// dx.doi.org/10.2139/ssrn.999265.

Johnson, S. A. (2003). Debt maturity and the effects of growth opportunities and liquidity risk on leverage. Review of Financial Studies, 16(1), 209-236.

Kale, J., \& Noe, T. (1990). Risky debt maturity choice in a sequential game equilibrium. Journal of Financial Research, 13, 155-166.

Kane, A., Marcus, A., \& MacDonald, R. (1985). Debt policy and the rate of return premium to leverage. Journal of Financial and Quantitative Analysis, 20, 479-499.

Kirch, G., \& Terra, P. R. S. (2012). Determinants of corporate debt maturity in South America: Do institutional quality and financial development matter? Journal of Corporate Finance, 18(4), 980-993.

Leland, H. E., \& Toft, K. B. (1996). Optimal capital structure, endogenous bankruptcy, and the term structure of credit spreads. The Journal of Finance, 51(3), 987-1019.

Llorente, G., Michaely, R., Saar, G., \& Wang, J. (2002). Dynamic volume-return relation of individual stocks. Review of Financial Studies, 15(4), 1005-1047.

Mackie-Mason, J. K. (1990). Do taxes affect corporate financing decisions? The Journal of Finance, 45(5), 1471-1493.

Meyer, K.E. (2001). International business research on transition economies., in A. Rugman and T. Brewer (eds.) Oxford handbook of international business, Oxford University Press: Oxford, pp: 716-759.

Morris, J. R. (1992). Factors affecting the maturity structure of corporate debt. University of Colorado at Denver.

Myers, S. C., \& Rajan, R. G. (1998). The paradox of liquidity. Quarterly Journal of Economics, 113, 733-771.

Myers, S. C. (1977). Determinants of corporate borrowings. Journal of Financial Economics, $5,147-175$

North, D. (1990). Institutions, institutional change, and economic performance. New York: Norton.

Ozkan, A. (2000). An empirical analysis of corporate debt maturity structure. European Financial Management, 6, 197-212.

Oztekin, O., \& Flannery, M. J. (2012). Institutional determinants of capital structure adjustment speeds. Journal of Financial Economics, 103, 88-112.

Qian, J., \& Strahan, P. E. (2007). How laws and institutions shape financial contracts: The case of bank loans. The Journal of Finance, 62(6), 2803-2834.

Rajan, R. G. (1992). Insiders and outsiders: The choice between informed and arm'slength debt. The Journal of Finance, 47(4), 1367-1400.

Sarkar, S. (1999). Illiquidity risk, project characteristics, and the optimal maturity of corporate debt. Journal of Financial Research, 22(3), 353-370.

Shyu, Y. -W., \& Lee, C. I. (2009). Excess control rights and debt maturity structure in family-controlled firms. Corporate Governance: An International Review, 17, 611-628.

Stiglitz, J. (1974). Perfect and imperfect capital markets. mimeo Oxford University.

Stohs, M., \& Mauer, D. (1996). The determinant of corporate debt maturity. Journal of Business, 69, 279-312.

Titman, S., \& Wessels, R. (1988). The determinants of capital structure choice. The Journal of Finance, 43(1), 1-19.

Turk-Ariss, R. (2009). Competitive behavior in Middle East and North Africa banking systems. The Quarterly Review of Economics and Finance, 49(2), 693-710.

Vig, V. (2013). Access to collateral and corporate debt structure: Evidence from a natural experiment. The Journal of Finance, 68(3), 881-928.

Wooldridge, J. M. (2002). Econometric analysis of cross section and panel data. Cambridge MA: MIT Press.

World Bank Group (2014). Doing business 2012. Doing business in a more transparent world. Washington, DC: The International Bank for Reconstruction and Development.

Zheng, X., El Ghoul, S., Guedhami, O., \& Kwok, C. C. (2012). National culture and corporate debt maturity. Journal of Banking \&' Finance, 36(2), 468-488. 